\title{
Surface Modification to Modulate Microbial Biofilms-Applications in Dental Medicine
}

\author{
Alina-Maria Holban ${ }^{1,2}$, Catalina Farcasiu ${ }^{3}$, Oana-Cella Andrei ${ }^{3}$, Alexandru Mihai Grumezescu ${ }^{2,4,5, *(D)}$ and \\ Alexandru-Titus Farcasiu ${ }^{3}$ (D) \\ 1 Microbiology \& Immunology Department, Faculty of Biology, University of Bucharest, \\ 77206 Bucharest, Romania; alina.m.holban@bio.unibuc.ro \\ 2 Research Institute of the University of Bucharest-ICUB, University of Bucharest, 050657 Bucharest, Romania \\ 3 "Carol Davila" University of Medicine and Pharmacy, 050474 Bucharest, Romania; \\ catalina.farcasiu@umfcd.ro (C.F.); oana.andrei@umfcd.ro (O.-C.A.); alexandru.farcasiu@umfcd.ro (A.-T.F.) \\ 4 Department of Science and Engineering of Oxide Materials and Nanomaterials, Faculty of Applied Chemistry \\ and Materials Science, Politehnica University of Bucharest, 011061 Bucharest, Romania \\ 5 Academy of Romanian Scientists, Ilfov No. 3, 50044 Bucharest, Romania \\ * Correspondence: grumezescu@yahoo.com
}

check for updates

Citation: Holban, A.-M.; Farcasiu, C.; Andrei, O.-C.; Grumezescu, A.M.;

Farcasiu, A.-T. Surface Modification to Modulate Microbial Biofilms-Applications in Dental Medicine. Materials 2021, 14, 6994 https://doi.org/10.3390/ma14226994

Academic Editor: Bruno Chrcanovic

Received: 6 October 2021

Accepted: 12 November 2021

Published: 18 November 2021

Publisher's Note: MDPI stays neutral with regard to jurisdictional claims in published maps and institutional affiliations.

Copyright: (c) 2021 by the authors. Licensee MDPI, Basel, Switzerland. This article is an open access article distributed under the terms and conditions of the Creative Commons Attribution (CC BY) license (https:// creativecommons.org/licenses/by/ $4.0 /)$.

\begin{abstract}
Recent progress in materials science and nanotechnology has led to the development of advanced materials with multifunctional properties. Dental medicine has benefited from the design of such materials and coatings in providing patients with tailored implants and improved materials for restorative and functional use. Such materials and coatings allow for better acceptance by the host body, promote successful implantation and determine a reduced inflammatory response after contact with the materials. Since numerous dental pathologies are influenced by the presence and activity of some pathogenic microorganisms, novel materials are needed to overcome this challenge as well. This paper aimed to reveal and discuss the most recent and innovative progress made in the field of materials surface modification in terms of microbial attachment inhibition and biofilm formation, with a direct impact on dental medicine.
\end{abstract}

Keywords: biofilm modulation; bacteria attachment; nano-modified surfaces; dental plaque; advanced materials

\section{Introduction}

Microbial biofilms are sessile multicellular communities acting as ultra-specialized groups of cells with different behavior and roles in the respective population [1]. Biofilms are studied for both their negative (i.e., medical biofilms that are resistant to high amounts of antibiotics and biofilm infections are very difficult to eradicate [2]) and positive (i.e., biofilm growth of an industrial bacteria into bioreactor enhances the production of the biomass and/or the desired bioproduct, such as enzyme or antibiotic [3]) impacts. This social lifestyle of microorganisms allows them to better adapt to various niches and is currently being exploited for numerous benefits. Industries, such as food, pharmaceutical and waste management, use attached microorganisms to obtain useful products and technologies.

Targeting microbial biofilms could be a beneficial approach in the prevention and treatment of many pathologies which involve a microbial component. Studies reported that more than $70 \%$ of difficult-to-treat and persistent infections are produced by microorganisms growing in biofilms. Together with genetic resistance of microbial strains, causing a worldwide crisis of antibiotic inefficiency, biofilms-embedded microorganisms show a diminished susceptibility to antimicrobials, a phenomenon known as tolerance or phenotypic resistance.

The dental plaque represents one of the most investigated multi-specific biofilms. It is an efficient model for understanding biofilms formation and relations between microor- 
ganisms in vitro and in vivo [4]. Dental plaque microbiota is very diverse, comprising over 700 microbial species, as molecular studies suggest [5], and at least 200 species have been identified as beneficial and are associated with dental health $[6,7]$. These include Abiotrophia defectiva, Streptococcus parasanguinis, Streptococcus mitis, Streptococcus oralis and Streptococcus sanguinis microbial strains [6]. On the other hand, biofilm pathogens comprise up to 100 bacterial species [8], including Streptococcus mutans, Veillonella spp., Lactobacillus casei, Lactobacillus reuteri, Actinomyces spp. and even Candida albicans [9-13].

Microbial biofilms are responsible for multiple dental pathologies, as demineralization of teeth, dental caries, prolonged inflammation and even pulp necrosis, leading to pulpitis and periapical gingivitis. Biofilms localized in the supra- and subgingival areas cause inflammation and degradation of supporting periodontal fibers, leading to bone and ultimately tooth loss. Most common diseased in this respect include chronic gingivitis and around dental implants infection (peri-implantitis) [8]. Materials utilized for dental crowns and caries treatment, as well as dental implants, become rapidly colonized by microorganisms, which are able to form thick and persistent biofilms (dental plaque), especially in difficult-to-reach areas, which remain untouched during daily hygiene.

Dental biofilm bacteria may spread to other body parts, causing bacteremia and systemic disease [10]. Therefore, efficient management of dental biofilms represents one of the most important steps in preventing and treating dental diseases.

Since microbial attachment on the oral surfaces represents the first step in biofilm development, researchers have made significant progress in elucidating attachment mechanisms and modulation. In dental medicine, the design and modification of materials aiming to improve physiological activities and aesthetics currently depend on the potential of such materials and surfaces to limit microbial colonization and the development of pathogenic biofilms [7].

Surface properties are important features of dental biomaterials and they have various functions. For example, high surface energy and rough surface texture encourage the adherence of cells forming regenerating tissues, but they may also facilitate microbial adherence. The main mechanism explaining adhesion stimulation is by increasing the contact surface. While hydrophilic surfaces enhance the adherence of host cells and microorganisms, superhydrophobic surfaces prevent this phenotype both in microbial and host cells (i.e., cells of regenerating tissues) [14-16].

The most investigated approaches are based on direct surface interventions, such as surface topology modifications, development of coatings for surface chemistry modification, photocatalytic applications or stimuli-responsive smart materials, that are able to detect pathogens and deliver particular antimicrobial agents to inhibit their attachment or kill bacteria [17]. Another approach relies on physical modification of the materials, which indirectly impact their antimicrobial properties by light, temperature or plasma treatment, which can be used to inhibit microbial attachment and remove mature biofilms [18].

Depending on the approached method, the antibacterial mechanisms of newly designed dental materials are very different (Figure 1), ranging from surfaces acting as repellents by inhibiting adherence $[15,19,20]$ to bioactive coatings [21-23], which specifically kill bacteria by various means, e.g., induction of membrane pores, stimulation of reactive oxygen species production [24], coupling to vital enzymes and/or DNA [25], inhibition of bacterial multiplication [26], etc. 


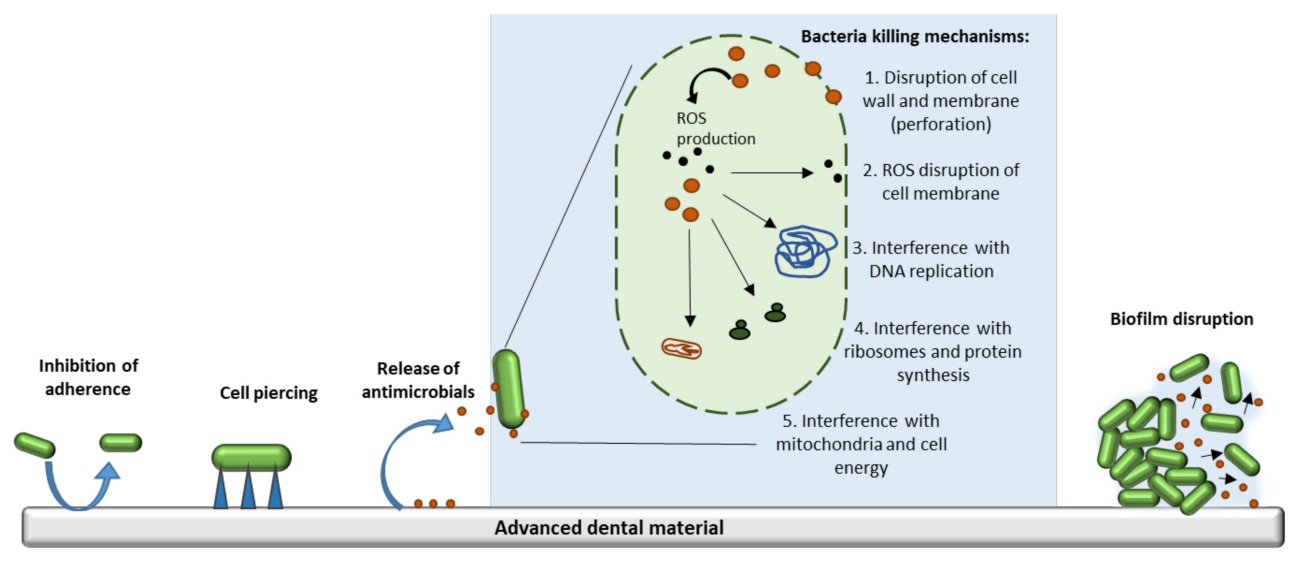

Figure 1. Antibacterial mechanisms in advanced dental materials. ROS = reactive oxygen species.

This review paper aimed to critically discuss surface modifications in dental materials that have recently been used to prevent microbial attachment and biofilm formation.

\section{Bacteria Attachment Factors}

Bacteria prefer to grow as attached communities on a surface (i.e., dental surfaces) rather than as free-floating cultures. This growth preference offers adaptive advantages and facilitates the occurrence of difficult-to-treat infections, since attached biofilm-embedded bacteria are up to 1000 times more resistant (tolerant) to antimicrobials and host immune systems than their planktonic counterparts [27]. Surface attachment of microorganisms occurs through non-specific interactions, such as van der Waals, electrostatic forces, hydrogen bonding and hydrophobic interactions.

Attachment to dental materials is a type of solid-liquid interface attachment. Solid materials represented by natural teeth or dental materials are surrounded by a liquid environment, which is represented by saliva. The outcome of this type of adherence is governed by factors related to the bacterium on one side, but also to the solid surface, and the liquid medium (saliva), on the other side. Table 1 represents the main factors involved in bacterial attachment in a solid-liquid model.

Table 1. Main Factors that Balance Bacterial Adherence to a Solid-Liquid Interface.

\begin{tabular}{|c|c|c|c|}
\hline Categories & Factors & Effects & References \\
\hline \multirow{4}{*}{ Bacterium related factors } & Surface charge & $\begin{array}{l}\text { Negative surface charged bacteria interacts better } \\
\text { with positively charged surfaces; the effect is } \\
\text { altered by high ionic strength media and can be } \\
\text { influenced by Quorum Sensing (QS) molecules } \\
\text { (i.e., acyl homoserine lactones (AHLs) }\end{array}$ & [28] \\
\hline & Surface energy & $\begin{array}{l}\text { The surface energy of bacteria is typically smaller } \\
\text { than the surface energy of the surrounded liquid; } \\
\text { therefore, microbial cells tend to adhere better to } \\
\text { hydrophobic materials }\end{array}$ & {$[28,29]$} \\
\hline & Shape and size & $\begin{array}{l}\text { Perpendicular or parallel orientation of bacteria } \\
\text { (i.e., rod-shaped) to a surface is possible to meet } \\
\text { the dimensional constraints but also } \\
\text { thermodynamic requirements }\end{array}$ & [29] \\
\hline & Appendages & $\begin{array}{l}\text { Ensure direct interference surface topographies, } \\
\text { detection of surface-associated } \\
\text { mechanical/chemical cues (i.e., fimbria and pili) }\end{array}$ & {$[28,30]$} \\
\hline
\end{tabular}


Table 1. Cont.

\begin{tabular}{|c|c|c|c|}
\hline Categories & Factors & Effects & References \\
\hline \multirow{3}{*}{ Bacterium related factors } & Adhesins & $\begin{array}{l}\text { Ensure surface colonization and facilitate cell-cell } \\
\text { cohesion (i.e., fimbrial and non-fimbrial proteins) }\end{array}$ & [31] \\
\hline & $\begin{array}{l}\text { Extracellular polymeric } \\
\text { substances }\end{array}$ & $\begin{array}{l}\text { Masking of the effective topographies, participate } \\
\text { to the conditioning film development (e.g., } \\
\text { capsula) }\end{array}$ & [29] \\
\hline & $\begin{array}{l}\text { Quorum Sensing (QS) } \\
\text { molecules }\end{array}$ & $\begin{array}{l}\text { Small signaling molecules detected by bacteria } \\
\text { cells which orchestrate the behavior of a complex } \\
\text { microbial community (i.e., AHLs) and alter the } \\
\text { movement of appendages, such as flagella, and the } \\
\text { cell surface charge) }\end{array}$ & {$[28,32]$} \\
\hline \multirow{6}{*}{ Liquid medium related factors } & Temperature & $\begin{array}{l}\text { Temperature changes reduce attachment and } \\
\text { biofilm development (i.e., biofilm development is } \\
\text { optimal at } 30^{\circ} \mathrm{C} \text { for most bacteria, but significantly } \\
\text { impaired at } 60-70^{\circ} \mathrm{C} \text { ) }\end{array}$ & [33] \\
\hline & Ionic strength & $\begin{array}{l}\text { Low ionic strengths inhibit bacterial adherence, } \\
\text { while higher ionic strengths facilitate irreversible } \\
\text { bacterial surface adherence (i.e., } 0.85 \% \text { saline } \\
\text { solution is optimal environment for adherence in } \\
\text { most bacteria) }\end{array}$ & [34] \\
\hline & Viscosity & $\begin{array}{l}\text { Viscous liquids impair microbial movement and } \\
\text { attachment }\end{array}$ & [28] \\
\hline & Surface tension & $\begin{array}{l}\text { The high surface tension of water is not } \\
\text { appropriate for bacteria to pierce the air-liquid } \\
\text { interface; therefore, it is expected that high ratios } \\
\text { of air-liquid to solid-liquid interfaces to inhibit } \\
\text { bacterial attachment (main mechanism is related to } \\
\text { the air entrapment) }\end{array}$ & {$[29,35]$} \\
\hline & Hydrodynamics & $\begin{array}{l}\text { Surface topography at the microscale can influence } \\
\text { hydrodynamics, which, in return, impact bacterial } \\
\text { attachment under flow conditions (motion and } \\
\text { deformation are key parameters) }\end{array}$ & {$[36,37]$} \\
\hline & $\mathrm{pH}$ & $\begin{array}{l}\text { Local } \mathrm{pH} \text { variations alter bacteria surface sensing, } \\
\text { attachment and biofilm formation (i.e., alkaline } \mathrm{pH} \\
\text { of } 7.4 \text { is optimal for biofilm development, while at } \\
\mathrm{pH} \text { of } 6.0 \text {, attachment and biofilm are significantly } \\
\text { impaired) }\end{array}$ & [38] \\
\hline \multirow{6}{*}{ Substratum related factors } & Surface charge & $\begin{array}{l}\text { Positively charged surfaces are colonized by } \\
\text { bacteria faster }\end{array}$ & [19] \\
\hline & Surface energy & $\begin{array}{l}\text { Low surface energy reduces surface wettability } \\
\text { and, thus, attachment }\end{array}$ & [19] \\
\hline & Topography & $\begin{array}{l}\text { (a) Roughness is the most deployed parameter, as } \\
\text { bacterial attachment is increased with higher } \\
\text { roughness; (b) spatial details, such as geometry, } \\
\text { periodicity, symmetry, density or hierarchical } \\
\text { structure of the surface characteristics, are } \\
\text { important for bacterial adherence }\end{array}$ & {$[29,39,40]$} \\
\hline & Stiffness & $\begin{array}{l}\text { Increasing stiffness of hydrophobic surfaces } \\
\text { correlates with decreasing adherence; on the other } \\
\text { hand, high stiffness of hydrophilic surfaces } \\
\text { increases bacterial adherence and biofilm } \\
\text { formation }\end{array}$ & {$[20,41,42]$} \\
\hline & & Modulate bacterial attachment by: & \\
\hline & Conditioning film & $\begin{array}{l}\text { (a) Surface properties changes of the neat } \\
\text { material surface; } \\
\text { (b) Surface topography changes; } \\
\text { (c) Bacteria-surface interactions particular sites. }\end{array}$ & {$[21,29]$} \\
\hline
\end{tabular}

Attachment is strongly determined by the electrical charges of the surface, hydrophobicity, hydrophilicity, wettability and topologies (i.e., roughness, geometry and other physical surface modifications) $[43,44]$. As most bacterial cells are negatively charged, 
surfaces which are also negatively charged generally repel bacteria cells and, thus, more resistant to colonization [45].

Bacteria adhere preferentially to irregular surfaces in order to maximize the bacteriasurface contact. However, this is dependent not only on the surface topographies but also on the sizes and shapes of the bacteria. Roughness, together with feature geometry, nanostructure [46], and surface physicochemistry can significantly interfere with bacterial adherence [47]. Concerning roughness, usually, a single indicator is used to describe this quantity, which is either Ra or Rq for 1D profiles or better Sa or Sq for 2D surfaces. However, these quantities only deal with the amplitude (height extension, in $\mathrm{z}$, normal to the surface background plane) of roughness. There are other classes of roughness parameters, so at least one parameter describing the texture, that is the patterning due to rough features as it appears from a projection to the $x-y$ base plane, should be considered. This deals with the spatial periodicity of the features. It is probably in this respect, that the single Sa value seem to give inconsistent results of bacterial adherence. This also depends on the spacing of the features: closely spaced ones (in the $x-y$ plane) provide hydrophobicity and no bacterial adherence. In addition, spikiness of the rough features (associated with kurtosis, as to the height distribution, so still just an amplitude parameter) could have an effect, since bacteria usually attach to more rounded features than very sharp ones, which usually puncture them [48].

\section{Surface Modifications in Dental Materials}

There are multiple materials utilized in dental medicine, ranging from cavity varnishes, cement and restorative resins to implantable materials [49]. Depending on their chemical composition, dental materials are divided into three categories: (i) metals (i.e., gold, Co-Cr alloys, stainless steel and titanium), (ii) ceramics (i.e., Al oxide, $\mathrm{Zr}$ oxide, hydroxyapatite, tricalcium phosphate, bioglass and carbon-silicon) and (iii) polymers (polyethylene, polyamide, polymethylmethacrylate, polytetrafluoroethylene and polyurethane).

Surface modification in dental materials depends on the material type and intended use [50]. Virtually any material utilized in dental medicine and implantology can be surface modified [51] to alter microbial attachment and biofilm formation. In this respect, the most investigated approaches rely on four directions: (i) inhibition of attachment by surface modification; (ii) material modifications to ensure local release of antimicrobials; (iii) contact-killing; and (iv) multifunctional strategy, usually employing multiple functions (e.g., remineralizing, protein-repellent, antimicrobial, etc.) [52]. Surface changes have a great impact in the design of novel dental materials, bringing significant advantages over traditional ones. However, there are some challenges and drawbacks that need to be overcome when designing new coatings and materials for medical purpose (Table 2).

Table 2. Advantages and Weaknesses in Dental Material Modifications.

\begin{tabular}{|c|c|c|c|}
\hline Material Modification & Advantages & Weaknesses & References \\
\hline Surface modification & $\begin{array}{l}\text { Inhibition of bacterial } \\
\text { adherence, limitation of } \\
\text { the pathogenic biofilm } \\
\text { formation }\end{array}$ & $\begin{array}{c}\text { May interfere with adherence } \\
\text { of regenerating cells and } \\
\text { tissues; also impair the } \\
\text { adherence of commensals }\end{array}$ & [53-56] \\
\hline $\begin{array}{l}\text { Chemical modification } \\
\text { to ensure drug release }\end{array}$ & $\begin{array}{l}\text { Targeted antibacterial } \\
\text { activity, controlled } \\
\text { release of the drug }\end{array}$ & $\begin{array}{l}\text { Local hypersensitivity, } \\
\text { inflammation }\end{array}$ & {$[22,24,27]$} \\
\hline Contact-killing & $\begin{array}{l}\text { High efficiency in } \\
\text { bacteria killing; rapid } \\
\text { effects }\end{array}$ & $\begin{array}{l}\text { Sometimes lacks the bacterial } \\
\text { killing specificity, it may } \\
\text { interfere with repair host cells } \\
\text { and tissues }\end{array}$ & [57] \\
\hline $\begin{array}{l}\text { Multifunctional coatings } \\
\text { and surfaces }\end{array}$ & $\begin{array}{l}\text { Versatility, high } \\
\text { efficiency, multiple } \\
\text { bioactivities for a } \\
\text { tailored therapy }\end{array}$ & $\begin{array}{l}\text { Unknown mid- and long-term } \\
\text { side effects }\end{array}$ & {$[44,58-60]$} \\
\hline
\end{tabular}


Figure 2 shows the most studied relevant modifications in dental materials to reduce microbial colonization and the development of pathogenic biofilms.

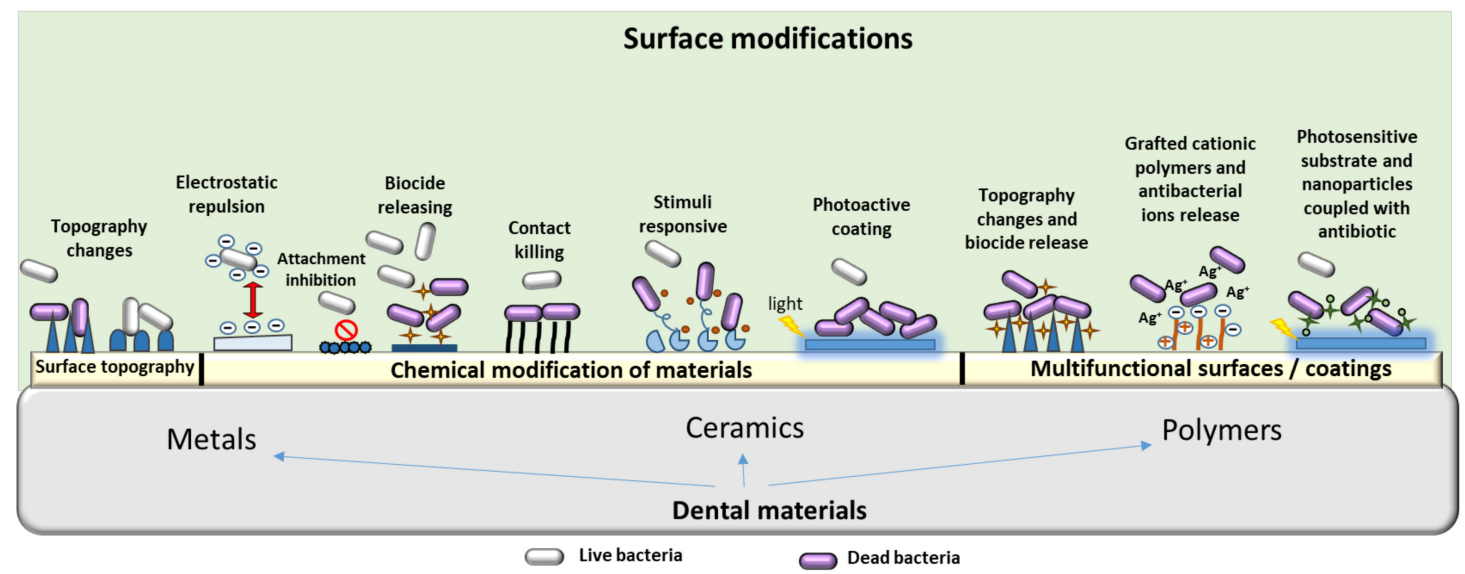

Figure 2. Surface modifications in dental materials investigated for their enhanced antibacterial activity. Upper part of the figure (pale green) shows different types of surface modifications which can be applied to various dental materials (i.e., metals and ceramics or polymers).

\subsection{Titanium-Based Materials}

Various studies have published the effects of topographical modifications of titaniumbased materials on bacterial adherence and survival.

Lorenzetti and coworkers investigated the surface modification of titanium-based substrates in order to inhibit bacterial adherence [53]. Such substrates are frequently utilized for the design of hard tissue implants, including dental. The surface of titanium dental materials can be modified by hydrothermal treatment to synthesize nanostructured $\mathrm{TiO}_{2}-$ anatase bioactive coatings. Titanium microasperities observed at the surface roughness (SR) scale represent a preferential site for attachment. In such conditions, individual cells interact intimately with the substrate on the valleys of the material containing high roughness. On the other hand, in $\mathrm{TiO}_{2}$-coated samples, the presence of nanocrystals was responsible for width reduction between the microasperities, thus adding nanoroughness features. This was translated into a decreased contact area between bacteria cells and the substrate, with up to $50 \%$ less bacterial adherence as compared to non-treated titanium material [53].

$\mathrm{TiO}_{2}$ nanowires obtained by hydrothermal oxidation reduce the Pseudomonas aeruginosa growth in the early stage of bacterial adherence, as compared with polished titanium. It was found that the titanium adherence of the dental pathogen Porphyromonas gingivalis was inhibited at SR levels below $R_{a} 350 \mathrm{~nm}$, a roughness level generally encountered for implant collars/abutments. [54] Some studies have revealed that $\mathrm{TiO}_{2}$ photo-activation leads to bacteria killing in five different pathogens (Escherichia coli, Pseudomonas aeruginosa, Staphylococcus aureus, Enterococcus hirae and Bacteroides fragilis [55,61].

Moreover, $\mathrm{TiO}_{2}$ surfaces can be photoactivated upon UV irradiation, and this phenomenon has a potential bactericidal effect of titania coatings under UV light (aspect known as photokilling) $[22,56,62]$. $\mathrm{TiO}_{2}$ surfaces with photocatalytic activity can also show photo-induced super hydrophilicity, which plays an important role in the bacterial adherence process, significantly affecting surface wettability [63]. However, as a recent study reports, the increased hydrophilicity of $\mathrm{HT}$-coated $\mathrm{TiO}_{2}$ discs obtained after UV irradiation produced no significant effects in Escherichia coli attachment [53].

Bacterial adherence on titanium-based surfaces with different nanotopograpy (i.e., nanotubular, nanotextured and nanorough) was also proved to be different. In recent years, several techniques for patterning material surfaces at the nanoscale [48], such as 
photolithography, polymer de-mixing, electron beam lithography and anodization, were developed [64].

In order to inhibit biofilm formation and show antibacterial properties, surface modification of titanium-based materials includes active antibacterial agents, such as antibiotics or nanoparticles (NPs), and repellent agents [65]. The selected bioactive agent also dictates the bacteriostatic/anti-adherence or bactericidal titanium surface character (Table 3).

Table 3. Surface Modifications for Achieving Antimicrobial Properties of Titanium-based Dental Materials.

\begin{tabular}{|c|c|c|c|c|c|}
\hline Surface Modifications & Methods & Effects & Antibacterial Mechanisms & Applications & References \\
\hline Low surface energy & $\begin{array}{l}\text { Plasma treatment, } \\
\text { chemical treatment (i.e., } \\
\text { sandblasting and/or } \\
\text { acid etching) }\end{array}$ & Anti-adherence & $\begin{array}{l}\text { Passive inhibition of bacterial } \\
\text { adherence }\end{array}$ & Dental implants & [58] \\
\hline Electrostatic repulsion & $\begin{array}{l}\text { Layer-by-layer } \\
\text { electrostatic } \\
\text { self-assembly }\end{array}$ & Anti-adherence & $\begin{array}{l}\text { Passive inhibition of bacterial } \\
\text { adherence by using ions coats }\end{array}$ & Dental implants & [55] \\
\hline $\begin{array}{l}\text { Exclusion steric } \\
\text { repulsion }\end{array}$ & Chemical grafting & Anti-adherence & $\begin{array}{l}\text { Passive inhibition of bacterial } \\
\text { adherence by using polymeric } \\
\text { coats }\end{array}$ & Various Ti implants & [55] \\
\hline $\begin{array}{l}\text { Contact active } \\
\text { bactericidal surfaces } \\
\text { containing synthetic } \\
\text { agents (i.e., quaternary } \\
\text { ammonium compounds } \\
\text { and polycations) }\end{array}$ & Polymeric coating & $\begin{array}{l}\text { Quaternary ammonium } \\
\text { compounds change the } \\
\text { bacterial cell essential } \\
\text { ionic balance, } \\
\text { disturbing the cellular } \\
\text { membrane. }\end{array}$ & $\begin{array}{l}\text { The active killing of bacteria } \\
\text { cells by direct binding to their } \\
\text { cell membrane and interaction } \\
\text { with the negatively charged } \\
\text { structures. }\end{array}$ & Dental implants & [57] \\
\hline $\begin{array}{c}\text { Contact active } \\
\text { bactericidal surfaces } \\
\text { containing natural } \\
\text { agents (i.e., } \\
\text { antimicrobial peptides } \\
\text { (AMPs)) }\end{array}$ & $\begin{array}{l}\text { Electrochemical } \\
\text { modification, coating }\end{array}$ & $\begin{array}{l}\text { AMPs (positively } \\
\text { charged) interact with } \\
\text { the bacterial } \\
\text { membranes (negatively } \\
\text { charged); involved in } \\
\text { membrane piercing and } \\
\text { DNA damaging }\end{array}$ & $\begin{array}{l}\text { Active killing by membrane } \\
\text { piercing due to competition } \\
\text { with calcium and magnesium } \\
\text { ions linked to the bacterial } \\
\text { polysaccharides; may attach on } \\
\text { the membrane via anionic } \\
\text { phospholipids and phosphate } \\
\text { groups of polysaccharides; } \\
\text { change the bacterial membrane } \\
\text { electrochemical gradient and } \\
\text { the cell morphology }\end{array}$ & $\begin{array}{l}\text { Ti-based dental } \\
\text { implants }\end{array}$ & [57] \\
\hline $\begin{array}{c}\text { Antibiotic releasing } \\
\text { surfaces }\end{array}$ & $\begin{array}{l}\text { Chemical grafting, } \\
\text { coating }\end{array}$ & & $\begin{array}{l}\text { Active killing by the specific } \\
\text { antibacterial mechanism }\end{array}$ & Ti bioactive implants & [59] \\
\hline
\end{tabular}

In recent years, plasma treatments have been developed for titanium implants. Such treatments are intensively investigated, since they stimulate osseointegration and bone differentiation without affecting surface properties [66]. Titanium dental implants treated with a non-thermal atmospheric pressure plasma jet demonstrated significant antibacterial activity against Gram-positive and Gram-negative strains [67]. A recent in vivo study performed in Labrador dogs has revealed that Ag-plasma modification stimulates bone apposition around $\mathrm{TiO}_{2}$ dental implants. Such an approach has promising antibacterial properties also, considering the well-known antibacterial and anti-biofilm properties of $\mathrm{Ag}$ and Ag ions [60]. Because of the versatility, antibacterial efficiency and good biocompatibility with human and animal tissues, atmospheric plasma treatments are expected to be intensively explored for in vivo antimicrobial applications in the near future.

\subsection{Ceramics}

The subgingival region of dental restoration is very important for preventing gingivitis secondary caries or peri-implantitis. The SR of this region is a key factor in this respect [68], considering that bacterial adherence to restorative materials varies upon the type of material [69]. Zirconia showed the lowest bacterial adherence compared to other restorative materials, such as leucite-reinforced ceramics, noble alloys or metal-based materials, without significant differences in the SR of studied materials [70]. Hahnel et al. [71] also cast doubt over the relationship between surface properties and bacterial adherence. They found significant differences between dental ceramic classes regarding roughness but could not conclude that the SR and surface energy alone can characterize bacterial adherence mechanisms. They also evaluated the effect of a protein coating from artificial 
saliva, which led to a significant increase in total surface free energy (SFE), as well as in its polar and dispersed components associated with lower bacterial adherence.

Astasov-Frauenhoffer et al. [72] investigated a polymer-infiltrated $\mathrm{Zr}$ ceramic and three dental types of cement specimens in relation to biofilm formation. Correlations were observed between inorganic/organic composition of the materials and the polar/dispersive part of SFE. The study concluded that the formation of a biofilm composed by Streptococcus sanguinis, Porphyromonas gingivalis and Fusobacterium nucleatum was increased in highwettability materials. It seems that a higher organic ratio is responsible for a lower biofilm formation ability, while a higher ceramic content results in an increased polarity and a decreased dispersity of the SFE.

Recently, Kozmos et al. investigated bacterial adherence of $S$. mutans to different dental ceramics. Interestingly, the highest bacterial adherence was observed on the yttrium stabilized tetragonal polycrystalline zirconia (Y-TZP), despite its having the lowest SR and the highest negative value of zeta potential. Correlations between those characteristics and cell adherence need to be further investigated for better material development. Surface properties, such as roughness, wettability and charge, significantly influence bacterial adherence extent [73]. Moreover, Engel et al. emphasized the importance of these characteristics next to material composition in biofilm maturation on specific restorative materials due to experimental discrepancies between the SR and thickness of the biofilm [74].

Dutra et al. [75] comprehensively reviewed the effect of finishing and polishing dental restorative materials on bacterial adherence, showing that such surface manipulations significantly affect the SR and promote a heterogeneous impact on bacterial adherence depending on the evaluated material. It is widely recognized that smoother surfaces are less likely to enhance biofilm formation. They concluded that (1) finishing procedures should always be followed by a polishing method, (2) polishing could reestablish the level of biofilm formation similar to untreated samples, (3) the range of the SR among polishing methods is wide and material dependent, (4) each dental material requires its smoothening method, (5) an SR threshold of $0.2 \mu \mathrm{m}$ did not properly predict biofilm formation for in vitro studies and (6) topographical irregularities of restorative materials had a higher impact for in vivo studies.

Intriguingly, it seems that the increased surface roughness after polishing did not increase the bacterial adherence [76-78], while Haralur et al. [79] reported that all polishing protocols failed to prevent bacterial adherence compared to glazed samples. While Dutra et al. tested Y-TZP ceramics, the other three studies evaluated feldspar-ceramics; therefore, the observed differences could be due to the chemical composition of the materials.

Surface properties of two translucent (5Y-ZP/8Y-ZP) and one conventional (3Y-TZP) zirconia substrates were evaluated by following a simulated clinical adjustment and intraoral finishing/polishing. The control SR was significantly higher for translucent zirconias compared to the conventional one. Material type and polishing had a statistically significant effect on SR. The four-step polishing protocol was the most efficient and exhibited the lowest surface roughness in 3Y-TZP and 5Y-TZP zirconia. The SR after this procedure was comparable to glazing for 3Y-TZP zirconia [80], in agreement with Incesu and Ianikoglu [81], who determined that the polishing performed by using an OptraFine kit (Ivoclar Vivadent AG, Schaan, Liechtenstein) determined a surface roughness of monolithic zirconia and feldspathic ceramic comparable to glazed surfaces. Scherrer et al. reported lower median roughness of zirconia and lithium disilicate ceramic than feldspathic ceramic irrespective of finishing method, emphasizing the effectiveness of chairside polishing kits, which determined an SR that was comparable to the control [82]. Poole et al. confirmed the positive correlation between the SR and colony-forming units (CFU) count of Prevotella intermedia, following a study on different ceramic systems [83]. Bremed et al. [84] reported significant differences in the bacterial surface coating and biofilm thickness between the various ceramic materials, following an in vivo study. HIP Y-TZP ceramic proved the lowest surface coating and biofilm thickness, while the highest values of these parameters were identified with the lithium disilicate glass-ceramic. 
Çakmak et al. [85] evaluated the effect of thermocycling on resin-matrix CAD-CAM ceramics (CeraSmart, GC Corporation, Tokyo, Japan) (CS)-nanoparticle (NP)-filled resin and Lava Ultimate (LU)-resin nano-ceramic) after different surface treatments. The WCA of CAD-CAM ceramics significantly increased after conventional polishing or coating with surface sealants both before and after thermocycling. The SR was significantly affected only before thermocycling. No significant correlation was found between the surface roughness and the WCA before and after thermocycling. However, the material significantly affected the WCA and SR after thermocycling. Contreras-Guerrero et al. reported a significant correlation between the SR of ceramics' or composites' use of S. mutans biofilm formation. The samples of ceramic restorative materials found under the name IPS E-Max CAD/CAM had the lowest SR and the lowest CFU value [86-88].

Fluor-apatite glass-ceramics disks were coated using plasma-enhanced chemical vapor-deposited $\mathrm{SiC}$ to improve material's antibacterial properties. The ceramic coating exhibited a film coverage of $19 \%$. On the other side, uncoated samples revealed a significantly higher coverage (of $91 \%$ ). The $\mathrm{SiC}$ coating presented bactericidal activity against S. mutans and S. sanguinis after $24 \mathrm{~h}$ of culture. The $\mathrm{SiC}$ coating produced no obvious cytotoxicity on human periodontal ligament fibroblasts. The coating slightly reduced the SR and significantly reduced the WCA [89].

Sang et al. investigated interactions between dental materials' surface, salivary pellicle and the oral colonizer Streptococcus gordonii at the physical-chemical level. The kinetics of pellicle adsorption formed pellicle thickness on four materials (gold, stainless steel, aluminum oxide and $\mathrm{Zr}$ oxide) were similar as proved by real-time monitoring of pellicle adsorption. Pellicle deposition on all materials increased the surface WCA, surface energy and adherence of bacteria. Authors observed that surfaces with well-developed pellicles contained more attached bacteria as compared to surfaces without a pellicle. However, the physical-chemical properties of the dental material did not significantly alter bacteria attachments. New dental materials are expected to be designed for controlling bacterial attachment by optimizing the structure, thickness and composition of the adsorbed salivary pellicle in the near future [45].

\subsection{Resin-Based Composite Materials (RBC)}

Three antibacterial strategies for resin-based restorative materials were recently described: antimicrobial agent release, contact-dependent strategies and multifunctional strategy, each with its advantages and disadvantages regarding surface properties evaluated below in recent publications [90]. The morphological, physical and chemical properties of resin-dentin interfacial degradation depend on the components and chemistry of restorative materials [91], thus influencing secondary caries at the resin-dentin interface.

The relationship between superficial properties and bacterial adherence was thoroughly investigated. Yuan et al. reported a strong correlation of $S$. mutans adherence with an SR ranging from 0.02 to $0.80 \mu \mathrm{m}$ and a weaker correlation with an $\mathrm{SR} \leq 0.20 \mu \mathrm{m}$. On super-smooth surfaces $(0.02-0.06 \mu \mathrm{m})$, bacterial adherence correlated positively with SFE. In conclusion [92]. Sainan et al. found a significant linear correlation between bacterial adherence forces and surface roughness. Furthermore, the SR exhibited less influence on the cariogenic strains than on the initial colonizers [93]. Derchi et al. reported only a partial correlation between the SR and bacterial adherence for direct dental composites [94]. CAD/CAM resin composite blocks are promising materials from a microbiological point of view, since they reduce biofilm formation in vitro when shear conditions are similar to in vivo ones [95].

Most of the recent studies that incorporate antibacterial additives into resin-based materials claim promising results. These bioactive compounds could be released and act specifically on the bacterial cells, determining targeted effects. Recent studies are reporting that novel dental materials could discriminate between commensal and pathogenic bacteria $[96,97]$. However, significant variability could be observed among such results 
and methodology, thus suggesting that they should be interpreted with caution. Surface modification was rarely investigated among the reviewed studies by Ibrahim et al. [98]

The addition of polyhexamethylene guanidine hydrochloride (PHMGH) inhibit biofilm formation to resin infiltrants. However, the critical physical properties of this material are not adversely influenced. It seems that resin infiltrants containing PHMGH at $1 \mathrm{wt} \%$ employed bactericidal and biofilm inhibition against $S$. mutans. The antibacterial activity is caused by a "contact-kill and release" mode of action. The WCA was slightly lower in modified samples, while the surface energy had the same levels in the test and control groups [99].

The incorporation of $2.5-10 \%$ mass fraction of dimethylaminododecyl methacrylate (DMADDM) improves the antibacterial effect expressed in S. mutans and limits demineralization of the tested resin. The SR and antibacterial ability have been preserved after one month of microbial-aging [100]. Dimethylaminohexadecyl methacrylate (DMAHDM) is another polymer with an antibacterial effect. Its addition decreased the biofilm CFU by 5-6 logs at 3\% DMAHDM. In association with $r n c$ deletion in S. mutans (which is an important gene for biofilm development), it had the greatest reaction in CFU by $8 \operatorname{logs}$ [101].

DMAHDM is also a material with proved antibacterial activity, being efficient against several bacteria involved in the pathogenesis of dental caries and periodontal disease. When combining DMAHDM and 2-methacryloyloxyethyl phosphorylcholine or silver NPs the antibacterial effect is significantly improved. Moreover, the association with NPs of amorphous calcium phosphate or calcium fluoride ensures enhanced remineralization capacity. The SR was investigated in three studies by adding 3\% and 5\% DMAHDM; all studies demonstrated no alterations in SR, even after biofilm challenges [102].

Wang et al. proposed a very interesting association between 2-methacryloyloxyethyl phosphorylcholine (MPC) and DMAHDM, which greatly inhibited the biofilm formation. The MPC+DMAHDM composite showed a similar SR to commercial composite and had a 3-fold greater surface charge [103].

Surface treatment to provide anti-biofouling nature was developed by using the chemical reaction of MPC with the composite resin. The treated surface showed significant resistance to oral protein adsorption and bacterial adherence in simulated physiological conditions. The contact angle with air bubbles in an aqueous medium significantly decreased after treatment, thus enhancing surface's wettability [104].

Lee et al. [105]. incorporated MPC in a pre-reacted glass-ionomer RBC. This study also reported a significant reduction of superficial protein adsorption and of the attachment of four-type bacteria and multispecies biofilm, inducing, at the same time, a decrease of the wettability (Table 4) of the modified RBC [105].

Table 4. Modification of Resin-based Composites to Achieve Surface Properties to Control Bacterial Attachment and Biofilm Formation.

\begin{tabular}{|c|c|c|c|}
\hline Methods & Materials & Surface Modifications & References \\
\hline \multirow{6}{*}{$\begin{array}{l}\text { Composition } \\
\text { modification }\end{array}$} & $\begin{array}{l}\text { Polyhexamethylene guanidine } \\
\text { hydrochloride (PHMGH) }\end{array}$ & $\begin{array}{l}\text { WET increased, } \\
\text { SFE control }\end{array}$ & [99] \\
\hline & DMADDM, DMAHDM & $\mathrm{SR} \sim$ control & [100-102] \\
\hline & MPC+DMAHDM & $\begin{array}{l}\text { SR control, SFE } \\
\text { increased }\end{array}$ & [103] \\
\hline & MPC & WET increased & [104] \\
\hline & $\begin{array}{l}\text { MPC in pre-reacted } \\
\text { glass-ionomer }\end{array}$ & WET decreased & [105] \\
\hline & $\begin{array}{c}\text { quaternary ammonium } \\
\text { polyethylenimine (QA-PEI) }\end{array}$ & $\begin{array}{c}\text { WET decrease } \\
\text { (hydrophilic surface) }\end{array}$ & [106] \\
\hline
\end{tabular}

Some studies showed significant improvements of antibacterial properties in composites dental materials containing more than $1 \mathrm{wt} \% \mathrm{ZnO}-\mathrm{NPs}$. However, the clinical advantage of these materials are questionable, mainly due to their short lifetime of observed antibacterial properties (similar CFU for modified and control samples after 1 and 
4 weeks). Surface modifications were not investigated among selected studies reviewed by Arun et al. [107].

Quaternary ammonium polyethyleneimine (QA-PEI) NPs were extensively evaluated in recent years to establish their potential as antibiocidal additives in dental composite materials. QA-PEI NPs are newly developed and promising dental-material additives that show unique antibacterial traits, while preserving the mechanical properties of the materials [108]. The addition of QA-PEI NPs determined an increased value of the WCA but remained within the range of hydrophilic surfaces, without significantly modifying other physiochemical and mechanical properties of the $1 \mathrm{wt} \%$ QA-PEI-modified resin [106], in addition to their proven antibacterial activity [109].

The antimicrobial properties of a micro-hybrid composite resin of varying SRs were investigated in vitro in multispecies biofilms in two time-points (at one and four days). Increased SR was not proportional to bacterial adherence. While for S. mutans and S. sobrinus some significant differences were found in relation to SR, the adhesion of $A$. actinomycetemcomitans and $P$. gingivalis to composite resin was not significantly influenced by SR. Adherence of S. mutans and S. sobrinus evaluated strains increased significantly from one to four days, whereas the adherence of periodontal pathogens decreased from one to four days (A. actinomycetemcomitans, $p<0.001 ; P$. gingivalis, $p=0.013$ ). The authors observed a decreased adherence of cariogenic streptococci and total bacteria at SR values of around $0.15 \mu \mathrm{m}$. These results support the idea that periodic finishing of SR minimize the adherence of cariogenic streptococci to composite resin surfaces [110].

The influence of surface treatments of different RBC on S. mutans biofilm formation was also analyzed. Cazzaniga et al., revealed that the RBCs may impact distinctly on $S$. mutans biofilm formation, suggesting that material characteristics and composition play a greater role than the SR [111].

Bilgili et al. investigated the relationship between surface-related properties of four novel bulk-fill composites and the adherence of S. mutans/S. mitis onto the resin surface. The authors reported no significant difference between materials in terms of the SR, but there were significant differences regarding the WCA and regarding SFE, with its dispersion component being the major contributor. Researchers concluded that the SR of bulk-fill composite resins did not affect bacterial adherence, which increased with higher SFE values, especially for $S$. mitis [112].

Ionescu et al. reported that polishing of different RBCs caused a significant decrease of SFE. This was also associated with an increase of surface silicon and a decrease of surface carbon. It seems that the ratio of resin matrix and filler particles on the surface of resin-based composites strongly influences in vitro biofilm formation in S. mutans strains. The anti-biofilm mechanism is explained by minimization of resin matrix exposure, which could be useful to reduce biofilm formation on the surface of RBCs [113]. Polishing diminishes biofilm formation and improves the surface properties of direct and indirect resin-based composites [114]. Candida sp. biofilm formation on the evaluated materials was significantly impaired, and this effect was modulated by the type of finishing and polishing method [115].

\subsection{Polymers}

Polymers have been widely investigated in the development and fabrication of removable dentures (Table 5). Among these, polymethylmethacrylate (PMMA) performed better than all others. Nevertheless, the major disadvantage of the PMMA is represented by the bacterial colonization due to the absence of ionic charge [115-117] and the absence of intrinsic antibacterial activity [116]. The unfinished fitting surface of dentures presents numerous irregularities, which help the adherence of microorganisms that are difficult to remove by mechanical or chemical cleaning [118]. Studies reported that $c$ adheres easily on this material, and it develops thick biofilms. Therefore, one of the most efficient approaches in preventing denture stomatitis is to reduce the initial adherence of C. albicans [23]. Denture stomatitis was reported to have a prevalence that ranges from $15 \%$ to $70 \%$ among 
patients [119]. We selected only studies presenting different methods of biofilm modulation associated with the analysis of surface modification.

The MPC polymers are well-investigated biomedical materials that are known for their significant biocompatibility and resistance to protein adsorption. MPC is safe as a biomaterial and has been investigated as an inhibitor of bacterial adherence on denture surfaces [120].

The surface of a PMMA resin denture base was successfully modified with MPC polymers by using a grafting polymerization technique. These surface changes retained antibacterial characteristics of the MPC against repetitive mechanical stress caused by friction induced by brushing [121]. The problem was to develop a procedure to bind MPC to denture base materials in a stable manner, as the previous grafting technique is expensive, complex and difficult to apply clinically. Ikeya et al. conducted an in vivo study on complete dentures that confirmed the viability of MPC in the form of 2-metahcryloyloxyethyl4 -azidobenzoate for inhibiting dental plaque formation for up to two weeks. This new monomer is photo-reactive and can polymerize with other monomers by conventional radical polymerization [120]. MPC (3\%) and DMAHDM $(1.5 \%)$ were mixed in a commercial acrylic resin, determining a much greater biofilm reduction than using MPC or DMAHDM alone. The acrylic resin kept its mechanical properties, while the average SR values were similar for MPC, DMAHDM, MPC+DMAHDM and control groups [122].

The addition of MPC or sulfobetaine methacrylate (SB), two zwitterionic materials, in 3D-printing PMMA determined a significant reduction in bacterial and biofilm adherence due to their protein-repellent properties. Although the mechanical properties were degraded, the reduction was minimal, and they maintained their resistance to the biofilm after hydrothermal fatigue. Both added materials decreased the WCA, which increased after thermocycling but reached lower values than control [123].

A study aiming to evaluate the microbial diversity of biofilm developed on the surface of acrylic resins modified with nanostructured silver vanadate $\left(\mathrm{AgVO}_{3}\right)$ functionalized with silver NPs showed significant differences in relation to the microbial diversity of modified resins during the initial phase of biofilm maturation. The experiments were performed in natural saliva and showed different microbial diversity of early and mature oral biofilm developed on the modified acrylic resins. It seems the presence of $\mathrm{AgVO}_{3}$ itself interfere with the bacterial colonization, and this phenomenon is not dependent on the incorporation method, and it did not change the SR [124].

$\mathrm{H} 2 \mathrm{~L}$ is a new ligand obtained after the polymerization of methylmethacrylate with sulfadiazine and its $\mathrm{Ag}^{+}$and $\mathrm{Sn}^{2+}$ at nanoscale. Studies reported that the modified denture base resin have stable thermal and physical properties. Since they show improved mechanical characteristics suitable for dental application, these materials could act as an intrinsic antifungal denture bases. The SR decreased in heat-polymerized acrylic resin after adding $\mathrm{H} 2 \mathrm{~L}, \mathrm{Ag}^{+}$and $\mathrm{Sn}^{2+}$ complexes [125].

Gad et al. [126] added zirconium dioxide and silver nanoparticles in different to the acrylic resin powder and found that the addition of zirconium dioxide nanoparticles to the denture base material in a double-layer technique decreased Candida sp. adherence and improved flexural strength without affecting the SR [126]. The increase in the SR can be explained by the difference in roughness between nano-ZrO2 and acrylic prosthesis base matrix, but also in the differences in the characteristics of the material in microscale and the shape of nano- $\mathrm{ZrO}_{2}$ or the inhomogeneous dispersion of nano- $\mathrm{ZrO}_{2}$ [127].

Methacrylate monomers containing metals were recently evaluated for their antifungal activity. This antimicrobial property does not interfere with the physicomechanical or optical properties of the denture base resin. Zirconium methacrylate (ZM), tin methacrylate (TM) and di-n-butyldimethacrylate-tin (DNBMT) are potential reactive agents for the fabrication of PMMA denture base resins with antimicrobial properties. The ZM, TM and DNBMT groups had higher antifungal activity against $C$. albicans and a lower SR than the control group [128]. 
Graphene oxide nanosheets (nGOs) and carbon nanotubes (CNTs) are carbon-based nanomaterials with proved antimicrobial effects. Their antibacterial mechanism is related mainly to direct contact bacteria killing properties [129-131]. Lee et al. [132] incorporated nGOs into PMMA to determine a sustained antimicrobial-adherence effects by increasing the wettability of PMMA. The addition of nGOs into PMMA roughened its surface and increased its wettability without compromising flexural strength or surface hardness. A sustained antimicrobial-adherence property manifested against C. albicans was observed in $2 \%$ nGOs for up to 28 days [132].

Han et al. investigated the incorporation of silver-based material (Novaron) in reinforced acrylic resins. Silanized aluminum borate whiskers (ABWs) (4 wt \%) and nano- $\mathrm{ZrO}_{2}$ $\left(2 \mathrm{wt} \%\right.$ ) were associated with PMMA to obtain nano- $\mathrm{ZrO}_{2}-\mathrm{ABW} / \mathrm{PMMA}$ matrices. Then, various amounts of Novaron particles were incorporated into the obtained matrices. The modified composite did not have an adverse cytotoxic effect and determined a significant reduction of S. mutans and C. albicans biofilm [133]. The SR depends on the amount and distribution of NPs, i.e., a uniform distribution, leading to surface hydrophobicity and to a smooth surface; and a chemical bond with the PMMA chain [134].

Incorporation of pre-reacted glass-ionomer filler slightly increases the SR of denture base resin, but it reduces the adherence of C. albicans. Materials containing at least of the $5 \%$ filler revealed a thinner biofilm as compared to the control group. All filler groups showed hyphal forms at $3 \mathrm{~h}$, with the length of the hyphae being lesser than those in the control group [135].

Using a hybrid process of plasma-based ion implantation and deposition, fluorine and silver ions were added into the PMMA resin. The obtained material proved a remarkable antibacterial activity and was associated with the development of a more hydrophobic surface. It seems that fluorine and silver dual-ion implantation and deposition can enhance antibacterial properties of novel acrylic medical and dental devices [136].

The addition of $\mathrm{Si}_{3} \mathrm{~N}_{4}$ ceramic particles ( $\sim \%$ vol.) in self-curing PMMA exhibited fungicidal action against $C$. albicans while being synergic with chemoprophylaxis. Investigations proved that there was no significant loss in bulk properties of the resin. Similar morphologies were observed for the PMMA and PMMA + 8\% vol. $\mathrm{Si}_{3} \mathrm{~N}_{4}$ substrates, except for the presence of some irregularities in the ceramic particles on the surface of the latter samples, had an increase of $26 \%$ in the mean roughness of the modified resin [137].

Studies demonstrate that, when adding 25 ppm copper $(\mathrm{Cu})$ NPs to denture base resins, the obtained material is significantly inhibiting biofilm formation of C. albicans dental strain. Although this study did not investigate surface properties, a surface modification is plausible. The antimicrobial role of $\mathrm{Cu}$ NPs could be substantiated with NPs piercing the microbial cell wall and stimulating the release of reactive oxygen species [138].

Poly(N-vinyl-2-pyrrolidinone)-grafted PMMA denture materials have been investigated a lot in recent years. One explanation regarding their popularity is that such materials can be repeatedly recharged with antimicrobial drugs. Sun et al. reported no physical properties and biocompatibility changes when the resins were modified by up to $7.92 \%$ of PNVP grafting. The model antimicrobial drugs were two antifungals, namely miconazole and chlorhexidine digluconate (CD). PNVP grafting significantly increased the antimicrobial substances absorption of the resulting denture materials. The released drugs showed potent antifungal and biofilm-formation effects against Candida sp. Grafting significantly improved the wettability of the resin surface [139].

The addition of dimethylaminohexadecyl methacrylate (DMAHDM) and chlorhexidine diacetate in a self-cured resin proved to increase antimicrobial activity against $S$. mutans or C. albicans significantly. The SR increased compared to control. No cytotoxic effect was recorded for this association [140].

Some studies reported that probiotics, such as L. rhamnosus and L. casei, interfere with Candida sp. biofilm initial formation and maturation. Neither of the probiotics affected the SR of the denture base resin, as recent studies report [141]. 
Chitosan NPs (ChNPs) have a widely recognized antimicrobial effect, being investigated both in bacteria and microscopic fungi. However, there is a limited information about the effects of ChNPs against Candida sp. biofilm on denture base surface. Recent studies showed antifungal activity of chitosan NPs against planktonic $C$. albicans, C. tropicalis and C. krusei. These NPs also inhibited the initial adherence and mature biofilm development in C. albicans. The chitosan NPs significantly reduced the CFU (colony forming units) of Candida spp. developed on acrylic surface containing such NPs after 5 days. These NPs reduce the SR and hardness of the material as compared to sodium hypochlorite, which is frequently used to disinfect denture [142].

Cold plasma treatment of PMMA denture base resin was recently investigated for oral medicine. This treatment could produce oxygen-containing polar hydroxyl, carbonyl and carboxyl groups at the polymer surface, thus increasing the SFE and wettability of the polymer and improving its adherence to oral tissues. Plasma modified of PMMA decreases the WCA by 1.5-2.5 times as compared to unmodified samples, while their SFE increased up to 1.5 times due to the formation of additional plasma induced oxygen-containing polar chemical groups. The plasma treated denture surface proved a good biocompatibility and less irritating effects, as compared to non-modified surfaces [143]. The wettability improvement of plasma-treated samples results from changes in surface morphology and surface chemistry [144].

Shibata et al. [145] evaluated a coating containing poly(2-methacryloyloxyethyl phosphorylcholine-co-n-butyl methacrylate) PMB which was developed for improving PMMA materials. This coating drastically reduced the ability of cariogenic bacteria, such as S. mutans and S. Sobrinus, to develop biofilms. Another study regarding the effects of MPC-polymer coating on denture base resins on the adherence of $C$. albicans, non-albicans Candida (NCAC) and methicillin-resistant Staphylococcus aureus (MRSA) was conducted by Fujiwara et al. [146]. MPC-polymer showed a limited effect against the growth of Candida sp. and MRSA strains evaluated, but it significantly suppressed adherence to denture resin in most of the evaluated microorganisms. The inhibition of adherence is caused by the increased hydrophobicity of the resin surface treated with $5 \%$ of MPC-polymer. The resulting surface proved to be significantly more hydrophilic and with a higher wettability. Turkcan et al. confirmed the MPC coating induced a significant increase in wettability, no differences regarding surface roughness and a significant decrease of C. albicans adherence [147].

Coatings based on resins prepared with a cross-linkable copolymer containing sulfobetaine methacrylamide (SBMAm) inhibited the adherence of C. albicans, as revealed by CFU results and SEM (scanning electron microscopy) images. Adherence inhibition expressed by the coating seems to be correlated with the wrinkle-based structures of the surfaces coated with copolymers containing more than 30\% SBMAm. However, the SR was not significantly different among all groups. In conclusion, cross-linkable copolymers containing SBMAm can enhance surface hydrophilicity in denture-base resins and reduce the initial adherence of $C$. albicans [23].

A plasma coating with trimethylsilane monomer was proved to significantly reduce the adherence of $C$. albicans to denture base resin. Plasma treatment exhibited a significantly more hydrophobic surface on which C. albicans was found to grow less than the control group, while adherence tests showed a significantly lower adherence of the $C$. albicans strains on the coated surfaces [148].

Polyacrylic acid (PAA) and poly itaconic acid (PIA) were tested as surface treatments on conventional denture base materials (Table 4). Both acids exhibited a significant $C$. albicans growth inhibition. The incorporation of carboxylic groups by using their coatings reduced the adherence of $C$. albicans by $90 \%$. Both acids improved the wettability of the substrates, but PAA significantly increased the roughness of both tested denture materials but had no cytotoxic effect on human cells [149].

The mechanical properties and SR of CAD-CAM PMMA resins are also improved, as compared with heat-polymerized polymethyl methacrylate resin. Conventional heatpolymerized PMMA resin proved to have higher SR values as compared to CAD-CAM 
PMMA resins [150]. Printable denture material was surface modified with nano silverloaded Zr phosphate (6S-NP3) obtained from simultaneous silanization of $\gamma$-methacryl oxypropyltrimethoxysilane (MPS) and grafting reaction of methyl methacrylate (MMA). This type of modification improved the material's mechanical properties but increased the WCA of the surface. The obtained composites proved great antibacterial activities against S. aureus and E. coli [151].

Mangal et al. [152] evaluated the role of nanodiamonds (NDs) as fillers to enhance the resistance to friction and wear but also the bacterial functions of dental materials. The control specimens without ND fillers were tested against specimens with both aminefunctionalized NDs (A-ND) and pure non-functionalized NDs. After the addition of $0.1 \mathrm{wt} \% \mathrm{ND}$ in the PMMA-based resin for 3D printing, the mechanical properties and resistance to bacteria colonization were significantly improved. This effect seems to be dependent on NDs' functionalization, while the SR proved no significant differences between sample groups. However, the SR increases in amine-functionalized surfaces.

Simoneti et al. [153] compared single interim crowns obtained by 3D-printing (laser stereolithography (SLA) and selective laser sintering (SLS)) and conventional methods with acrylic resin and bis-acryl resin regarding mechanical properties and biofilm formation. The SR presented significant variations when comparing the improved materials, being different before and after finishing. The conventional materials and SLA presented similar SRs, which were lower as compared to SLS value. Biofilm development showed insignificant variations on these materials.

Table 5. Modification Strategy inP to Achieve Surface Properties to Control Bacterial Attachment and Biofilm Formation.

\begin{tabular}{|c|c|c|c|}
\hline Methods & Materials & Surface Modifications & References \\
\hline \multirow{6}{*}{ Composition modification } & $\begin{array}{l}\text { MPC, DMAHDM, MPC+DMAHDM, } \\
\mathrm{AgVO}_{3} \text { nanodiamonds }\end{array}$ & SR $\sim$ control & {$[122,124,152]$} \\
\hline & $\begin{array}{c}\mathrm{H} 2 \mathrm{~L}+\mathrm{Ag}^{+} / \mathrm{Sn}^{2+}, \text { Zirconium methacrylate, } \\
\text { Tin methacrylate, } \\
\text { di-n-butyldimethacrylate-tin }\end{array}$ & SR decreased & {$[125,128]$} \\
\hline & Graphene-oxide nanosheets (nGo) & SR increased WET increased & [132] \\
\hline & $\begin{array}{l}\mathrm{ZrO}_{2} \text {, pre-reacted glass ionomer, } \mathrm{Si}_{3} \mathrm{~N}_{4} \\
\text { ceramic particles, DMAHDM }+ \\
\text { chlorhexidine diacetate }\end{array}$ & SR increased & {$[127,135,137,140]$} \\
\hline & Fluorine and silver ions & WET decreased & [136] \\
\hline & $\begin{array}{l}\text { Poly(N-vinyl-2-pyrrolidinone), SB } \\
\text { (sulfobetaine methacrylate), MPC }\end{array}$ & WET increased & {$[123,139]$} \\
\hline \multirow{2}{*}{ Surface treatments } & Probiotics, chitosan & SR control & {$[141,142]$} \\
\hline & Cold plasma & WET increased SFE increased & [144] \\
\hline \multirow{4}{*}{ Coatings } & MPC, sulfobetaine methacrylamide & WET increased SR control & {$[23,147]$} \\
\hline & $\begin{array}{l}\text { Trimethylsilane, nano silver-loaded } \\
\text { zirconium phosphate }\end{array}$ & WET decreased & {$[148,151]$} \\
\hline & Poly acrylic acid & SR increased WET increased & [149] \\
\hline & Poly itaconic acid & WET increased & [149] \\
\hline
\end{tabular}

\section{Conclusions}

This paper aimed to reveal the amount and diversity of surface modifications for improved dental materials, highlighting the approaches utilized for obtaining antimicrobial and anti-biofilm effects. The limitation of microbial attachment, which is the first step in biofilm formation, still remains a target when designing dental medicine materials. However, there is a series of challenges in designing ideal dental materials when it comes to their surface properties. Novel materials and coatings should be smooth enough to allow the attachment and proliferation of the host's soft tissues' attachment and proliferation, while limiting the adherence and biofilm formation of dental pathogens. Moreover, the attachment of oral microbiota on dental surfaces could be beneficial for maintaining the balance for oral health. In recent years, particular attention was given to the smart, stimuliresponsive or functional materials, which could be capable of inhibiting attachment to ensure the targeted killing of dental pathogens. However, additional studies are still 
necessary to reveal the intimate antibacterial mechanisms and how these will impact the management of oral diseases. Certainly, significant research on these novel materials is needed to confirm a real breakthrough in the longevity of restorative dental materials and their efficiency and potential side effects at mid- and long-term utilization.

Author Contributions: Conceptualization, A.-M.H., C.F., O.-C.A., A.M.G. and A.-T.F.; methodology, A.-M.H., C.F., O.-C.A., A.M.G. and A.-T.F.; investigation, A.-M.H., C.F., O.-C.A., A.M.G. and A.-T.F.; writing-original draft preparation, A.-M.H., C.F., O.-C.A., A.M.G. and A.-T.F.; writing-review and editing, A.-M.H., C.F., O.-C.A., A.M.G. and A.-T.F. All authors have read and agreed to the published version of the manuscript.

Funding: This work was supported by a grant of the Ministry of Research, Innovation and Digitization, CNCS/CCCDI-UEFISCDI, project number 271PED/2020 within PNCDI III.

Institutional Review Board Statement: Not applicable.

Informed Consent Statement: Not applicable.

Data Availability Statement: Not applicable.

Conflicts of Interest: The authors declare no conflict of interest.

\section{References}

1. Lazar, V. Quorum sensing in biofilms-How to destroy the bacterial citadels or their cohesion/power? Anaerobe 2011, 17, 280-285. [CrossRef] [PubMed]

2. Uruén, C.; Chopo-Escuin, G.; Tommassen, J.; Mainar-Jaime, R.C.; Arenas, J. Biofilms as Promoters of Bacterial Antibiotic Resistance and Tolerance. Antibiotics 2021, 10,3. [CrossRef] [PubMed]

3. Qureshi, N.; Annous, B.A.; Ezeji, T.C.; Karcher, P.; Maddox, I.S. Biofilm reactors for industrial bioconversion processes: Employing potential of enhanced reaction rates. Microb. Cell Factories 2005, 4, 24. [CrossRef] [PubMed]

4. Jakubovics, N.S.; Goodman, S.D.; Mashburn-Warren, L.; Stafford, G.P.; Cieplik, F. The dental plaque biofilm matrix. Periodontology 2000 2021, 86, 32-56. [CrossRef]

5. Chen, T.; Yu, W.-H.; Izard, J.; Baranova, O.V.; Lakshmanan, A.; Dewhirst, F.E. The Human Oral Microbiome Database: A web accessible resource for investigating oral microbe taxonomic and genomic information. Database 2010, 2010, baq013. [CrossRef]

6. Corby, P.M.; Lyons-Weiler, J.; Bretz, W.A.; Hart, T.C.; Aas, J.A.; Boumenna, T.; Goss, J.; Corby, A.L.; Junior, H.M.; Weyant, R.J.; et al. Microbial risk indicators of early childhood caries. J. Clin. Microbiol. 2005, 43, 5753-5759. [CrossRef]

7. Bowen, W.H.; Burne, R.A.; Wu, H.; Koo, H. Oral Biofilms: Pathogens, Matrix, and Polymicrobial Interactions in Microenvironments. Trends Microbiol. 2018, 26, 229-242. [CrossRef]

8. Larsen, T.; Fiehn, N.E. Dental biofilm infections-An update. APMIS Acta Pathol. Microbiol. Immunol. Scand. 2017, 125, 376-384. [CrossRef]

9. Wen, Z.T.; Yates, D.; Ahn, S.J.; Burne, R.A. Biofilm formation and virulence expression by Streptococcus mutans are altered when grown in dual-species model. BMC Microbiol. 2010, 10, 111. [CrossRef]

10. Baker, J.L.; Faustoferri, R.C.; Quivey, R.G. Acid-adaptive mechanisms of Streptococcus mutans-The more we know, the more we don't. Mol. Oral Microbiol. 2017, 32, 107-117. [CrossRef]

11. Richards, V.P.; Alvarez, A.J.; Luce, A.R.; Bedenbaugh, M.; Mitchell, M.L.; Burne, R.A.; Nascimento, M.M. Microbiomes of Site-Specific Dental Plaques from Children with Different Caries Status. Infect. Immun. 2017, 85, e00106-17. [CrossRef]

12. Kim, D.; Sengupta, A.; Niepa, T.H.; Lee, B.H.; Weljie, A.; Freitas-Blanco, V.S.; Murata, R.M.; Stebe, K.J.; Lee, D.; Koo, H. Candida albicans stimulates Streptococcus mutans microcolony development via cross-kingdom biofilm-derived metabolites. Sci. Rep. 2017, 7, 41332. [CrossRef]

13. Hooshdar, P.; Kermanshahi, R.K.; Ghadam, P.; Khosravi-Darani, K. A Review on Production of Exopolysaccharide and Biofilm in Probiotics Like Lactobacilli and Methods of Analysis. Biointerface Res. Appl. Chem. 2020, 10, 6058-6075. [CrossRef]

14. Ramburrun, P.; Pringle, N.A.; Dube, A.; Adam, R.Z.; D'Souza, S.; Aucamp, M. Recent Advances in the Development of Antimicrobial and Antifouling Biocompatible Materials for Dental Applications. Materials 2021, 14, 3167. [CrossRef]

15. Yuan, Y.; Hays, M.P.; Hardwidge, P.R.; Kim, J. Surface characteristics influencing bacterial adhesion to polymeric substrates. RSC Adv. 2017, 7, 14254-14261. [CrossRef]

16. De-la-Pinta, I.; Cobos, M.; Ibarretxe, J.; Montoya, E.; Eraso, E.; Guraya, T.; Quindós, G. Effect of biomaterials hydrophobicity and roughness on biofilm development. J. Mater. Sci. Mater. Med. 2019, 30, 77. [CrossRef]

17. Sharifi, S.; Samani, A.; Ahmadian, E.; Eftekhari, A.; Derakhshankhah, H.; Jafari, S.; Mokhtarpour, M.; Zununi Vahed, S.; Salatin, S.; Maleki Dizaj, S. Oral delivery of proteins and peptides by mucoadhesive nanoparticles. Biointerface Res. Appl. Chem. 2019, 9 , 3849-3852.

18. Jungbauer, G.; Moser, D.; Müller, S.; Pfister, W.; Sculean, A.; Eick, S. The Antimicrobial Effect of Cold Atmospheric Plasma against Dental Pathogens-A Systematic Review of In-Vitro Studies. Antibiotics 2021, 10, 211. [CrossRef] 
19. Zheng, S.; Bawazir, M.; Dhall, A.; Kim, H.E.; He, L.; Heo, J.; Hwang, G. Implication of Surface Properties, Bacterial Motility, and Hydrodynamic Conditions on Bacterial Surface Sensing and Their Initial Adhesion. Front. Bioeng. Biotechnol. 2021, $9,643722$. [CrossRef]

20. Kolewe, K.W.; Zhu, J.; Mako, N.R.; Nonnenmann, S.S.; Schiffman, J.D. Bacterial Adhesion Is Affected by the Thickness and Stiffness of Poly(ethylene glycol) Hydrogels. ACS Appl. Mater. Interfaces 2018, 10, 2275-2281. [CrossRef]

21. Bakker, D.P.; Busscher, H.J.; van Zanten, J.; de Vries, J.; Klijnstra, J.W.; van der Mei, H.C. Multiple linear regression analysis of bacterial deposition to polyurethane coatings after conditioning film formation in the marine environment. Microbiology 2004, 150, 1779-1784. [CrossRef]

22. Gallardo-Moreno, A.M.; Pacha-Olivenza, M.A.; Fernández-Calderón, M.-C.; Pérez-Giraldo, C.; Bruque, J.M.; González-Martín, M.-L. Bactericidal behaviour of Ti6Al4V surfaces after exposure to UV-C light. Biomaterials 2010, 31, 5159-5168. [CrossRef]

23. Hirasawa, M.; Tsutsumi-Arai, C.; Takakusaki, K.; Oya, T.; Fueki, K.; Wakabayashi, N. Superhydrophilic co-polymer coatings on denture surfaces reduce Candida albicans adhesion-An in vitro study. Arch. Oral Biol. 2018, 87, 143-150. [CrossRef]

24. Liu, F.; Hong, T.; Xie, J.; Zhan, X.; Wang, Y. Application of Reactive Oxygen Species-Based Nanomaterials in Dentistry: A Review. Crystals 2021, 11, 266. [CrossRef]

25. Koo, H.; Allan, R.N.; Howlin, R.P.; Stoodley, P.; Hall-Stoodley, L. Targeting microbial biofilms: Current and prospective therapeutic strategies. Nat. Rev. Microbiol. 2017, 15, 740-755. [CrossRef]

26. Rawashdeh, R.Y.; Sawafta, R.; Malkawi, H.I. Dental Materials Incorporated with Nanometals and Their Effect on the Bacterial Growth of Staphylococcus aureus. Int. J. Nanomed. 2020, 15, 4325-4331. [CrossRef]

27. Sharma, D.; Misba, L.; Khan, A.U. Antibiotics versus biofilm: An emerging battleground in microbial communities. Antimicrob. Resist. Infect. Control. 2019, 8, 76. [CrossRef]

28. Tuson, H.H.; Weibel, D.B. Bacteria-Surface interactions. Soft Matter 2013, 9, 4368-4380. [CrossRef]

29. Cheng, Y.; Feng, G.; Moraru, C.I. Micro- and Nanotopography Sensitive Bacterial Attachment Mechanisms: A Review. Front. Microbiol. 2019, 10, 191. [CrossRef]

30. Friedlander, R.S.; Vlamakis, H.; Kim, P.; Khan, M.; Kolter, R.; Aizenberg, J. Bacterial flagella explore microscale hummocks and hollows to increase adhesion. Proc. Natl. Acad. Sci. USA 2013, 110, 5624-5629. [CrossRef]

31. Rickard, A.H.; Gilbert, P.; High, N.J.; Kolenbrander, P.E.; Handley, P.S. Bacterial coaggregation: An integral process in the development of multi-species biofilms. Trends Microbiol. 2003, 11, 94-100. [CrossRef]

32. Eboigbodin, K.E.; Newton, J.R.; Routh, A.F.; Biggs, C.A. Bacterial quorum sensing and cell surface electrokinetic properties. Appl. Microbiol. Biotechnol. 2006, 73, 669-675. [CrossRef] [PubMed]

33. Kirschner, C.M.; Brennan, A.B. Bio-Inspired Antifouling Strategies. Annu. Rev. Mater. Res. 2012, 42, 211-229. [CrossRef]

34. Hori, K.; Matsumoto, S. Bacterial adhesion: From mechanism to control. Biochem. Eng. J. 2010, 48, 424-434. [CrossRef]

35. Marmur, A. Underwater superhydrophobicity: Theoretical feasibility. Langmuir ACS J. Surf. Colloids 2006, 22, 1400-1402. [CrossRef]

36. Halder, P.; Nasabi, M.; Lopez, F.J.; Jayasuriya, N.; Bhattacharya, S.; Deighton, M.; Mitchell, A.; Bhuiyan, M.A. A novel approach to determine the efficacy of patterned surfaces for biofouling control in relation to its microfluidic environment. Biofouling 2013, 29, 697-713. [CrossRef]

37. Lee, Y.K.; Won, Y.-J.; Yoo, J.H.; Ahn, K.H.; Lee, C.-H. Flow analysis and fouling on the patterned membrane surface. J. Membr. Sci. 2013, 427, 320-325. [CrossRef]

38. Ponsonnet, L.; Boureanu, M.; Jaffrezic, N.; Othmane, A.; Dorel, C.; Lejeune, P. Local pH variation as an initial step in bacterial surface-sensing and biofilm formation. Mater. Sci. Eng. C 2008, 28, 896-900. [CrossRef]

39. Verran, J.; Boyd, R.D. The relationship between substratum surface roughness and microbiological and organic soiling: A review. Biofouling 2001, 17, 59-71. [CrossRef]

40. Crawford, R.J.; Webb, H.K.; Truong, V.K.; Hasan, J.; Ivanova, E.P. Surface topographical factors influencing bacterial attachment. Adv. Colloid Interface Sci. 2012, 179, 142-149. [CrossRef]

41. Song, F.; Wang, H.; Sauer, K.; Ren, D. Cyclic-di-GMP and oprF Are Involved in the Response of Pseudomonas aeruginosa to Substrate Material Stiffness during Attachment on Polydimethylsiloxane (PDMS). Front. Microbiol. 2018, 9, 110. [CrossRef]

42. Lichter, J.A.; Thompson, M.T.; Delgadillo, M.; Nishikawa, T.; Rubner, M.F.; Van Vliet, K.J. Substrata Mechanical Stiffness Can Regulate Adhesion of Viable Bacteria. Biomacromolecules 2008, 9, 1571-1578. [CrossRef]

43. Lv, J.; Jin, J.; Chen, J.; Cai, B.; Jiang, W. Antifouling and Antibacterial Properties Constructed by Quaternary Ammonium and Benzyl Ester Derived from Lysine Methacrylamide. ACS Appl. Mater. Interfaces 2019, 11, 25556-25568. [CrossRef]

44. Li, W.; Thian, E.S.; Wang, M.; Wang, Z.; Ren, L. Surface Design for Antibacterial Materials: From Fundamentals to Advanced Strategies. Adv. Sci. 2021, 8, 2100368. [CrossRef]

45. Sang, T.; Ye, Z.; Fischer, N.G.; Skoe, E.P.; Echeverría, C.; Wu, J.; Aparicio, C. Physical-chemical interactions between dental materials surface, salivary pellicle and Streptococcus gordonii. Colloids Surf. B Biointerfaces 2020, 190, 110938. [CrossRef]

46. Abdelghany, A.; Kamal, M.K.; Shalaby, R.; Abogabal, R. Antimicrobial effect, electronic and structural correlation of nano-filled Tin Bismuth metal alloys for biomedical applications. Biointerface Res. Appl. Chem. 2019, 9, 110889. [CrossRef]

47. Rajab, F.H.; Liauw, C.M.; Benson, P.S.; Li, L.; Whitehead, K.A. Picosecond laser treatment production of hierarchical structured stainless steel to reduce bacterial fouling. Food Bioprod. Process. 2018, 109, 29-40. [CrossRef] 
48. Salerno, M.; Itri, A.; Frezzato, M.; Rebaudi, A. Surface microstructure of dental implants before and after insertion: An in vitro study by means of scanning probe microscopy. Implant. Dent. 2015, 24, 248-255. [CrossRef]

49. Moore, B.K. Chapter 16-Dental Materials. In McDonald and Avery Dentistry for the Child and Adolescent, 9th ed.; Dean, J.A., Avery, D.R., McDonald, R.E., Eds.; Mosby: St. Louis, MO, USA, 2011; pp. 296-312.

50. Ahangari, Z.; Khodadadi, E.; Ezoji, F.; Khafri, S. Comparative Evaluation of Microtensile Bond Strength of Three Restorative Materials. Biointerface Res. Appl. Chem. 2020, 10, 6688-6694. [CrossRef]

51. Ciocca, L.; Lesci, I.; Ragazzini, S.; Gioria, S.; Valsesia, A.; Parrilli, A.; Spadari, A.; Dozza, B.; Mora, P.; Piattelli, A.J.B.R.A.C. Nanostructured surface bioactive composite scaffold for filling of bone defects. Biointerface Res. Appl. Chem. 2020, 10, 5038-5047.

52. Jiao, Y.; Tay, F.R.; Niu, L.N.; Chen, J.H. Advancing antimicrobial strategies for managing oral biofilm infections. Int. J. Oral Sci. 2019, 11, 28. [CrossRef]

53. Lorenzetti, M.; Dogša, I.; Stošicki, T.; Stopar, D.; Kalin, M.; Kobe, S.; Novak, S. The influence of surface modification on bacterial adhesion to titanium-based substrates. ACS Appl. Mater. Interfaces 2015, 7, 1644-1651. [CrossRef]

54. Amoroso, P.F.; Adams, R.J.; Waters, M.G.; Williams, D.W. Titanium surface modification and its effect on the adherence of Porphyromonas gingivalis: An in vitro study. Clin. Oral Implant. Res. 2006, 17, 633-637. [CrossRef]

55. Orapiriyakul, W.; Young, P.S.; Damiati, L.; Tsimbouri, P.M. Antibacterial surface modification of titanium implants in orthopaedics. J. Tissue Eng. 2018, 9, 2041731418789838. [CrossRef]

56. Omrani, M.M.; Hadjizadeh, A.; Milani, A.; Kim, K. PEEK surface modification methods and effect of the laser method on surface properties. Biointerface Res. Appl. Chem. 2020, 10, 5132-5140. [CrossRef]

57. Mitwalli, H.; Alsahafi, R.; Balhaddad, A.A.; Weir, M.D.; Xu, H.H.K.; Melo, M.A.S. Emerging Contact-Killing Antibacterial Strategies for Developing Anti-Biofilm Dental Polymeric Restorative Materials. Bioengineering 2020, 7, 83. [CrossRef]

58. Al-Radha, A.S.; Dymock, D.; Younes, C.; O'Sullivan, D. Surface properties of titanium and zirconia dental implant materials and their effect on bacterial adhesion. J. Dent. 2012, 40, 146-153. [CrossRef]

59. Souza, J.G.S.; Bertolini, M.M.; Costa, R.C.; Nagay, B.E.; Dongari-Bagtzoglou, A.; Barão, V.A.R. Targeting implant-associated infections: Titanium surface loaded with antimicrobial. iScience 2021, 24, 102008. [CrossRef] [PubMed]

60. Qiao, S.; Cao, H.; Zhao, X.; Lo, H.; Zhuang, L.; Gu, Y.; Shi, J.; Liu, X.; Lai, H. Ag-plasma modification enhances bone apposition around titanium dental implants: An animal study in Labrador dogs. Int. J. Nanomed. 2015, 10, 653-664. [CrossRef]

61. Kubacka, A.; Diez, M.S.; Rojo, D.; Bargiela, R.; Ciordia, S.; Zapico, I.; Albar, J.P.; Barbas, C.; Martins dos Santos, V.A.; FernándezGarcía, M.; et al. Understanding the antimicrobial mechanism of $\mathrm{TiO}_{2}$-based nanocomposite films in a pathogenic bacterium. Sci. Rep. 2014, 4, 4134. [CrossRef] [PubMed]

62. Badry, R.; Ibrahim, A.; Gamal, F.; Shehata, D.; Ezzat, H.; Elhaes, H.; Ibrahim, M. Electronic Properties of Polyvinyl Alcohol $/ \mathrm{TiO}_{2} / \mathrm{SiO}_{2}$ Nanocomposites. Biointerface Res. Appl. Chem. 2020, 10, 6427-6435. [CrossRef]

63. Katsikogianni, M.; Missirlis, Y.F. Concise review of mechanisms of bacterial adhesion to biomaterials and of techniques used in estimating bacteria-material interactions. Eur. Cells Mater. 2004, 8, 37-57. [CrossRef]

64. Puckett, S.D.; Taylor, E.; Raimondo, T.; Webster, T.J. The relationship between the nanostructure of titanium surfaces and bacterial attachment. Biomaterials 2010, 31, 706-713. [CrossRef]

65. Azmi, A.; Ahyat, N.; Mohamad, F.; Hamzah, S.J.B.R.A.C. Synthesis of silver nanoparticles: Double-green approach of using chitosan and microwave technique towards antimicrobial activity against pathogenic bacteria. Biointerface Res. Appl. Chem. 2020, 10, 5918-5922.

66. Ujino, D.; Nishizaki, H.; Higuchi, S.; Komasa, S.; Okazaki, J. Effect of Plasma Treatment of Titanium Surface on Biocompatibility. Appl. Sci. 2019, 9, 2257. [CrossRef]

67. Lee, M.-J.; Kwon, J.-S.; Jiang, H.B.; Choi, E.H.; Park, G.; Kim, K.-M. The antibacterial effect of non-thermal atmospheric pressure plasma treatment of titanium surfaces according to the bacterial wall structure. Sci. Rep. 2019, 9, 1938. [CrossRef]

68. Rashid, H. The effect of surface roughness on ceramics used in dentistry: A review of literature. Eur. J. Dent. 2014, 8, 571-579. [CrossRef]

69. Kenawy, S.H.; Khalil, A.M. Advanced ceramics and relevant polymers for environmental and biomedical applications. Biointerface Res. Appl. Chem. 2020, 10, 5747-5754. [CrossRef]

70. Jalalian, E.; Shalchi, M.; Hajian-Tilaki, A.; Aghajani Nargesi, R. Adhesion of Streptococcus Mutans to Zirconia, Enamel, IPS Empress II, Noble Alloy and Base-metal: An In-Vitro Comparative Study. J. Dentomaxillofac. Radiol. Pathol. Surg. 2018, 7, 1-6. [CrossRef]

71. Hahnel, S.; Rosentritt, M.; Handel, G.; Bürgers, R. Surface characterization of dental ceramics and initial streptococcal adhesion in vitro. Dent. Mater. Off. Publ. Acad. Dent. Mater. 2009, 25, 969-975. [CrossRef]

72. Astasov-Frauenhoffer, M.; Glauser, S.; Fischer, J.; Schmidli, F.; Waltimo, T.; Rohr, N. Biofilm formation on restorative materials and resin composite cements. Dent. Mater. 2018, 34, 1702-1709. [CrossRef]

73. Kozmos, M.; Virant, P.; Rojko, F.; Abram, A.; Rudolf, R.; Raspor, P.; Zore, A.; Bohinc, K. Bacterial Adhesion of Streptococcus mutans to Dental Material Surfaces. Molecules 2021, 26, 1152. [CrossRef]

74. Engel, A.-S.; Kranz, H.T.; Schneider, M.; Tietze, J.P.; Piwowarcyk, A.; Kuzius, T.; Arnold, W.; Naumova, E.A. Biofilm formation on different dental restorative materials in the oral cavity. BMC Oral Health 2020, 20, 162. [CrossRef]

75. Dutra, D.; Pereira, G.; Kantorski, K.Z.; Valandro, L.F.; Zanatta, F.B. Does Finishing and Polishing of Restorative Materials Affect Bacterial Adhesion and Biofilm Formation? A Systematic Review. Oper. Dent. 2018, 43, E37-E52. [CrossRef] 
76. Kawai, K.; Urano, M.; Ebisu, S. Effect of surface roughness of porcelain on adhesion of bacteria and their synthesizing glucans. J. Prosthet. Dent. 2000, 83, 664-667. [CrossRef]

77. Brentel, A.S.; Kantorski, K.Z.; Valandro, L.F.; Fúcio, S.B.; Puppin-Rontani, R.M.; Bottino, M.A. Confocal laser microscopic analysis of biofilm on newer feldspar ceramic. Oper. Dent. 2011, 36, 43-51. [CrossRef]

78. Dutra, D.; Pereira, G.; Kantorski, K.; Exterkate, R.; Kleverlaan, C.; Valandro, L.; Zanatta, F. Grinding with Diamond Burs and Hydrothermal Aging of a Y-TZP Material: Effect on the Material Surface Characteristics and Bacterial Adhesion. Oper. Dent. 2017, 42, 669-678. [CrossRef]

79. Haralur, S.B. Evaluation of efficiency of manual polishing over autoglazed and overglazed porcelain and its effect on plaque accumulation. J. Adv. Prosthodont. 2012, 4, 179-186. [CrossRef]

80. Jum'ah, A.A.; Brunton, P.A.; Li, K.C.; Waddell, J.N. Simulated clinical adjustment and intra-oral polishing of two translucent, monolithic zirconia dental ceramics: An in vitro investigation of surface roughness. J. Dent. 2020, 101, 103447. [CrossRef]

81. Incesu, E.; Yanikoglu, N. Evaluation of the effect of different polishing systems on the surface roughness of dental ceramics. J. Prosthet. Dent. 2020, 124, 100-109. [CrossRef]

82. Scherrer, D.; Bragger, U.; Ferrari, M.; Mocker, A.; Joda, T. In-vitro polishing of CAD/CAM ceramic restorations: An evaluation with SEM and confocal profilometry. J. Mech. Behav. Biomed. Mater. 2020, 107, 103761. [CrossRef] [PubMed]

83. Poole, S.F.; Pitondo-Silva, A.; Oliveira-Silva, M.; Moris, I.C.M.; Gomes, E.A. Influence of different ceramic materials and surface treatments on the adhesion of Prevotella intermedia. J. Mech. Behav. Biomed. Mater. 2020, 111, 104010. [CrossRef] [PubMed]

84. Bremer, F.; Grade, S.; Kohorst, P.; Stiesch, M. In vivo biofilm formation on different dental ceramics. Quintessence Int. 2011, 42, 565-574. [PubMed]

85. Çakmak, G.; Subaşı, M.G.; Yilmaz, B. Effect of thermocycling on the surface properties of resin-matrix CAD-CAM ceramics after different surface treatments. J. Mech. Behav. Biomed. Mater. 2021, 117, 104401. [CrossRef]

86. Contreras-Guerrero, P.; Ortiz-Magdaleno, M.; Urcuyo-Alvarado, M.S.; Cepeda-Bravo, J.A.; Leyva-Del Rio, D.; Pérez-López, J.E.; Romo-Ramírez, G.F.; Sánchez-Vargas, L.O. Effect of dental restorative materials surface roughness on the in vitro biofilm formation of Streptococcus mutans biofilm. Am. J. Dent. 2020, 33, 59-63.

87. Daskalova, A.; Angelova, L.; Carvalho, A.; Trifonov, A.; Nathala, C.; Monteiro, F.; Buchvarov, I. Effect of surface modification by femtosecond laser on zirconia based ceramics for screening of cell-surface interaction. Appl. Surf. Sci. 2020, 513, 145914. [CrossRef]

88. Llama-Palacios, A.; Sánchez, M.C.; Díaz, L.A.; Cabal, B.; Suárez, M.; Moya, J.S.; Torrecillas, R.; Figuero, E.; Sanz, M.; Herrera, D. In vitro biofilm formation on different ceramic biomaterial surfaces: Coating with two bactericidal glasses. Dent. Mater. Off. Publ. Acad. Dent. Mater. 2019, 35, 883-892. [CrossRef]

89. Afonso Camargo, S.E.; Mohiuddeen, A.S.; Fares, C.; Partain, J.L.; Carey, P.H.T.; Ren, F.; Hsu, S.M.; Clark, A.E.; Esquivel-Upshaw, J.F. Anti-Bacterial Properties and Biocompatibility of Novel SiC Coating for Dental Ceramic. J. Funct. Biomater. 2020, 11, 33. [CrossRef]

90. Sun, Q.; Zhang, L.; Bai, R.; Zhuang, Z.; Zhang, Y.; Yu, T.; Peng, L.; Xin, T.; Chen, S.; Han, B. Recent Progress in Antimicrobial Strategies for Resin-Based Restoratives. Polymers 2021, 13, 1590. [CrossRef]

91. Zhou, Y.; Matin, K.; Shimada, Y.; Sadr, A.; Wang, G.; Tagami, J.; Feng, X. Characteristics of biofilm-induced degradation at resin-dentin interfaces using multiple combinations of adhesives and resins. Dent. Mater. Off. Publ. Acad. Dent. Mater. 2021, 37, 1260-1272. [CrossRef]

92. Yuan, C.; Wang, X.; Gao, X.; Chen, F.; Liang, X.; Li, D. Effects of surface properties of polymer-based restorative materials on early adhesion of Streptococcus mutans in vitro. J. Dent. 2016, 54, 33-40. [CrossRef]

93. Sainan, Z.; Li, J.; Lei, Z.; Liying, H.; Lu, Y.; Wei, L. Influence of surface roughness on oral streptococcal adhesion forces to dental filling materials. West China J. Stomatol. 2016, 34, 448-453. [CrossRef]

94. Derchi, G.; Vano, M.; Barone, A.; Covani, U.; Diaspro, A.; Salerno, M. Bacterial adhesion on direct and indirect dental restorative composite resins: An in vitro study on a natural biofilm. J. Prosthet. Dent. 2017, 117, 669-676. [CrossRef]

95. Ionescu, A.C.; Hahnel, S.; König, A.; Brambilla, E. Resin composite blocks for dental CAD/CAM applications reduce biofilm formation in vitro. Dent. Mater. Off. Publ. Acad. Dent. Mater. 2020, 36, 603-616. [CrossRef]

96. Trautner, B.W.; Lopez, A.I.; Kumar, A.; Siddiq, D.M.; Liao, K.S.; Li, Y.; Tweardy, D.J.; Cai, C. Nanoscale surface modification favors benign biofilm formation and impedes adherence by pathogens. Nanomed. Nanotechnol. Biol. Med. 2012, 8, 261-270. [CrossRef]

97. Chen, Q.; Zhu, Z.; Wang, J.; Lopez, A.I.; Li, S.; Kumar, A.; Yu, F.; Chen, H.; Cai, C.; Zhang, L. Probiotic E. coli Nissle 1917 biofilms on silicone substrates for bacterial interference against pathogen colonization. Acta Biomater. 2017, 50, 353-360. [CrossRef]

98. Ibrahim, M.S.; Garcia, I.M.; Kensara, A.; Balhaddad, A.A.; Collares, F.M.; Williams, M.A.; Ibrahim, A.S.; Lin, N.J.; Weir, M.D.; Xu, H.H.K.; et al. How we are assessing the developing antibacterial resin-based dental materials? A scoping review. J. Dent. 2020, 99, 103369. [CrossRef]

99. Collares, F.M.; Garcia, I.M.; Bohns, F.R.; Motta, A.; Melo, M.A.; Leitune, V.C.B. Guanidine hydrochloride polymer additive to undertake ultraconservative resin infiltrant against Streptococcus mutans. Eur. Polym. J. 2020, 133, 109746. [CrossRef]

100. Yu, J.; Huang, X.; Zhou, X.; Han, Q.; Zhou, W.; Liang, J.; Xu, H.H.K.; Ren, B.; Peng, X.; Weir, M.D.; et al. Anti-caries effect of resin infiltrant modified by quaternary ammonium monomers. J. Dent. 2020, 97, 103355. [CrossRef] 
101. Chen, H.; Zhang, B.; Weir, M.D.; Homayounfar, N.; Fay, G.G.; Martinho, F.; Lei, L.; Bai, Y.; Hu, T.; Xu, H.H.K.S. S. mutans gene-modification and antibacterial resin composite as dual strategy to suppress biofilm acid production and inhibit caries. $J$. Dent. 2020, 93, 103278. [CrossRef]

102. Duarte de Oliveira, F.J.; Ferreira da Silva Filho, P.S.; Fernandes Costa, M.J.; Rabelo Caldas, M.R.G.; Dutra Borges, B.C.; Gadelha de Araújo, D.F. A comprehensive review of the antibacterial activity of dimethylaminohexadecyl methacrylate (DMAHDM) and its influence on mechanical properties of resin-based dental materials. Jpn. Dent. Sci. Rev. 2021, 57, 60-70. [CrossRef]

103. Wang, L.; Xie, X.; Qi, M.; Weir, M.D.; Reynolds, M.A.; Li, C.; Zhou, C.; Xu, H.H.K. Effects of single species versus multispecies periodontal biofilms on the antibacterial efficacy of a novel bioactive Class-V nanocomposite. Dent. Mater. Off. Publ. Acad. Dent. Mater. 2019, 35, 847-861. [CrossRef]

104. Koyama, J.; Fukazawa, K.; Ishihara, K.; Mori, Y. In situ surface modification on dental composite resin using 2-methacryloyloxyethyl phosphorylcholine polymer for controlling plaque formation. Mater. Sci. Eng. C Mater. Biol. Appl. 2019, 104, 109916. [CrossRef]

105. Lee, M.J.; Kwon, J.S.; Kim, J.Y.; Ryu, J.H.; Seo, J.Y.; Jang, S.; Kim, K.M.; Hwang, C.J.; Choi, S.H. Bioactive resin-based composite with surface pre-reacted glass-ionomer filler and zwitterionic material to prevent the formation of multi-species biofilm. Dent. Mater. Off. Publ. Acad. Dent. Mater. 2019, 35, 1331-1341. [CrossRef]

106. Barszczewska-Rybarek, I.M.; Chrószcz, M.W.; Chladek, G. Physicochemical and Mechanical Properties of Bis-GMA/TEGDMA Dental Composite Resins Enriched with Quaternary Ammonium Polyethylenimine Nanoparticles. Materials 2021, $14,2037$. [CrossRef]

107. Arun, D.; Adikari Mudiyanselage, D.; Gulam Mohamed, R.; Liddell, M.; Monsur Hassan, N.M.; Sharma, D. Does the Addition of Zinc Oxide Nanoparticles Improve the Antibacterial Properties of Direct Dental Composite Resins? A Systematic Review. Materials 2021, 14, 40. [CrossRef]

108. Chrószcz, M.; Barszczewska-Rybarek, I. Nanoparticles of Quaternary Ammonium Polyethylenimine Derivatives for Application in Dental Materials. Polymers 2020, 12, 2551. [CrossRef]

109. Beyth, N.; Yudovin-Farber, I.; Bahir, R.; Domb, A.J.; Weiss, E.I. Antibacterial activity of dental composites containing quaternary ammonium polyethylenimine nanoparticles against Streptococcus mutans. Biomaterials 2006, 27, 3995-4002. [CrossRef]

110. Park, J.W.; An, J.S.; Lim, W.H.; Lim, B.S.; Ahn, S.J. Microbial changes in biofilms on composite resins with different surface roughness: An in vitro study with a multispecies biofilm model. J. Prosthet. Dent. 2019, 122, 493.e1-493.e8. [CrossRef]

111. Cazzaniga, G.; Ottobelli, M.; Ionescu, A.C.; Paolone, G.; Gherlone, E.; Ferracane, J.L.; Brambilla, E. In vitro biofilm formation on resin-based composites after different finishing and polishing procedures. J. Dent. 2017, 67, 43-52. [CrossRef]

112. Bilgili, D.; Dündar, A.; Barutçugil, Ç.; Tayfun, D.; Özyurt, Ö.K. Surface properties and bacterial adhesion of bulk-fill composite resins. J. Dent. 2020, 95, 103317. [CrossRef] [PubMed]

113. Ionescu, A.; Wutscher, E.; Brambilla, E.; Schneider-Feyrer, S.; Giessibl, F.J.; Hahnel, S. Influence of surface properties of resin-based composites on in vitro Streptococcus mutans biofilm development. Eur. J. Oral Sci. 2012, 120, 458-465. [CrossRef] [PubMed]

114. Kurt, A.; Cilingir, A.; Bilmenoglu, C.; Topcuoglu, N.; Kulekci, G. Effect of different polishing techniques for composite resin materials on surface properties and bacterial biofilm formation. J. Dent. 2019, 90, 103199. [CrossRef] [PubMed]

115. Oktay, E.A.; Ersahan, S.; Sabuncuoglu, F.A.; Tort, H.; Karaoglanoglu, S. Impact of various finishing and polishing techniques and composite materials on Candida albicans biofilm formation. Med. Mycol. 2020, 58, 698-702. [CrossRef]

116. He, J.; Söderling, E.; Lassila, L.V.; Vallittu, P.K. Incorporation of an antibacterial and radiopaque monomer in to dental resin system. Dent. Mater. Off. Publ. Acad. Dent. Mater. 2012, 28, e110-e117. [CrossRef]

117. Park, S.E.; Blissett, R.; Susarla, S.M.; Weber, H.P. Candida albicans adherence to surface-modified denture resin surfaces. J. Prosthodont. Off. J. Am. Coll. Prosthodont. 2008, 17, 365-369. [CrossRef]

118. Redding, S.; Bhatt, B.; Rawls, H.R.; Siegel, G.; Scott, K.; Lopez-Ribot, J. Inhibition of Candida albicans biofilm formation on denture material. Oral Surg. Oral Med. Oral Pathol. Oral Radiol. Endod. 2009, 107, 669-672. [CrossRef]

119. Gendreau, L.; Loewy, Z.G. Epidemiology and etiology of denture stomatitis. J. Prosthodont. Off. J. Am. Coll. Prosthodont. 2011, 20, 251-260. [CrossRef]

120. Ikeya, K.; Iwasa, F.; Inoue, Y.; Fukunishi, M.; Takahashi, N.; Ishihara, K.; Baba, K. Inhibition of denture plaque deposition on complete dentures by 2-methacryloyloxyethyl phosphorylcholine polymer coating: A clinical study. J. Prosthet. Dent. 2018, 119, 67-74. [CrossRef]

121. Takahashi, N.; Iwasa, F.; Inoue, Y.; Morisaki, H.; Ishihara, K.; Baba, K. Evaluation of the durability and antiadhesive action of 2-methacryloyloxyethyl phosphorylcholine grafting on an acrylic resin denture base material. J. Prosthet. Dent. 2014, 112, 194-203. [CrossRef]

122. Cao, L.; Xie, X.; Wang, B.; Weir, M.D.; Oates, T.W.; Xu, H.H.K.; Zhang, N.; Bai, Y. Protein-repellent and antibacterial effects of a novel polymethyl methacrylate resin. J. Dent. 2018, 79, 39-45. [CrossRef]

123. Kwon, J.S.; Kim, J.Y.; Mangal, U.; Seo, J.Y.; Lee, M.J.; Jin, J.; Yu, J.H.; Choi, S.H. Durable Oral Biofilm Resistance of 3D-Printed Dental Base Polymers Containing Zwitterionic Materials. Int. J. Mol. Sci. 2021, 22, 417. [CrossRef]

124. De Castro, D.T.; do Nascimento, C.; Alves, O.L.; de Souza Santos, E.; Agnelli, J.A.M.; Dos Reis, A.C. Analysis of the oral microbiome on the surface of modified dental polymers. Arch. Oral Biol. 2018, 93, 107-114. [CrossRef]

125. Elwakiel, N.; El-Sayed, Y.; Elkafrawy, H. Synthesis, characterization of $\mathrm{Ag}^{+}$and $\mathrm{Sn}^{2+}$ complexes and their applications to improve the biological and mechanical properties of denture base materials. J. Mol. Struct. 2020, 1219, 128521. [CrossRef] 
126. Gad, M.M.; Abualsaud, R.; Rahoma, A.; Al-Thobity, A.M.; Akhtar, S.; Fouda, S.M. Double-layered acrylic resin denture base with nanoparticle additions: An in vitro study. J. Prosthet. Dent. 2020, 123, 386. [CrossRef]

127. Ergun, G.; Sahin, Z.; Ataol, A.S. The effects of adding various ratios of zirconium oxide nanoparticles to poly(methyl methacrylate) on physical and mechanical properties. J. Oral Sci. 2018, 60, 304-315. [CrossRef]

128. Da Silva Barboza, A.; Fang, L.K.; Ribeiro, J.S.; Cuevas-Suárez, C.E.; Moraes, R.R.; Lund, R.G. Physicomechanical, optical, and antifungal properties of polymethyl methacrylate modified with metal methacrylate monomers. J. Prosthet. Dent. 2021, 125, 706.e1-706.e6. [CrossRef]

129. Chen, J.; Peng, H.; Wang, X.; Shao, F.; Yuan, Z.; Han, H. Graphene oxide exhibits broad-spectrum antimicrobial activity against bacterial phytopathogens and fungal conidia by intertwining and membrane perturbation. Nanoscale 2014, 6, 1879-1889. [CrossRef]

130. Badry, R.; Radwan, S.H.; Ezzat, D.; Ezzat, H.; Elhaes, H.; Ibrahim, M. Study of the Electronic Properties of Graphene Oxide/(PANi/Teflon). Biointerface Res. Appl. Chem. 2020, 10, 6926-6935. [CrossRef]

131. Zindani, D.; Kumar, K. Graphene-based polymeric nano-composites: An introspection into functionalization, processing techniques and biomedical applications. Biointerface Res. Appl. Chem. 2019, 9, 3926-3933. [CrossRef]

132. Lee, J.H.; Jo, J.K.; Kim, D.A.; Patel, K.D.; Kim, H.W.; Lee, H.H. Nano-graphene oxide incorporated into PMMA resin to prevent microbial adhesion. Dent. Mater. Off. Publ. Acad. Dent. Mater. 2018, 34, e63-e72. [CrossRef]

133. Han, Z.; Zhu, B.; Chen, R.; Huang, Z.; Zhu, C.; Zhang, X. Effect of silver-supported materials on the mechanical and antibacterial properties of reinforced acrylic resin composites. Mater. Des. 2015, 65, 1245-1252. [CrossRef]

134. Selim, M.S.; El-Safty, S.A.; El-Sockary, M.A.; Hashem, A.I.; Abo Elenien, O.M.; El-Saeed, A.M.; Fatthallah, N.A. Modeling of spherical silver nanoparticles in silicone-based nanocomposites for marine antifouling. RSC Adv. 2015, 5, 63175-63185. [CrossRef]

135. Tsutsumi, C.; Takakuda, K.; Wakabayashi, N. Reduction of Candida biofilm adhesion by incorporation of prereacted glass ionomer filler in denture base resin. J. Dent. 2016, 44, 37-43. [CrossRef]

136. Shinonaga, Y.; Arita, K. Antibacterial effect of acrylic dental devices after surface modification by fluorine and silver dual-ion implantation. Acta Biomater. 2012, 8, 1388-1393. [CrossRef]

137. Pezzotti, G.; Asai, T.; Adachi, T.; Ohgitani, E.; Yamamoto, T.; Kanamura, N.; Boschetto, F.; Zhu, W.; Zanocco, M.; Marin, E.; et al. Antifungal activity of polymethyl methacrylate/ $\left.\mathrm{Si}_{3}\right) \mathrm{N}\left({ }_{4}\right)$ composites against Candida albicans. Acta Biomater. 2021, 126, 259-276. [CrossRef]

138. Patnaik, A.; Aiyer, P.; Gali, S.R.D. Flexural strength and anti-fungal activity of copper nano-particles on poly-methyl methacrylate denture base resins. Mater. Today Proc. 2021, 46, 8761-8766. [CrossRef]

139. Sun, X. Antifungal activity, biofilm-controlling effect, and biocompatibility of poly(N-vinyl-2-pyrrolidinone)-grafted denture materials. Colloids Surf. B Biointerfaces 2013, 110, 96-104. [CrossRef]

140. Campos, K.P.L.; Viana, G.M.; Cabral, L.M.; Portela, M.B.; Hirata, R., Jr.; Cavalcante, L.M.; Lourenço, E.J.V.; Telles, D.M. Self-cured resin modified by quaternary ammonium methacrylates and chlorhexidine: Cytotoxicity, antimicrobial, physical, and mechanical properties. Dent. Mater. Off. Publ. Acad. Dent. Mater. 2020, 36, 68-75. [CrossRef]

141. Song, Y.G.; Lee, S.H. Inhibitory effects of Lactobacillus rhamnosus and Lactobacillus casei on Candida biofilm of denture surface. Arch. Oral Biol. 2017, 76, 1-6. [CrossRef]

142. Gondim, B.L.C.; Castellano, L.R.C.; de Castro, R.D.; Machado, G.; Carlo, H.L.; Valença, A.M.G.; de Carvalho, F.G. Effect of chitosan nanoparticles on the inhibition of Candida spp. biofilm on denture base surface. Arch. Oral Biol. 2018, 94, 99-107. [CrossRef] [PubMed]

143. Vasilieva, T.; Hein, A.M.; Vargin, A.; Kudasova, E.; Kochurova, E.; Nekludova, M. The effect of polymeric denture modified in low-temperature glow discharge on human oral mucosa: Clinical case. Clin. Plasma Med. 2018, 9, 1-5. [CrossRef]

144. Chang, Y.T.; Chen, G. Oral bacterial inactivation using a novel low-temperature atmospheric-pressure plasma device. J. Dent. Sci. 2016, 11, 65-71. [CrossRef] [PubMed]

145. Shibata, Y.; Yamashita, Y.; Tsuru, K.; Ishihara, K.; Fukazawa, K.; Ishikawa, K. Preventive effects of a phospholipid polymer coating on PMMA on biofilm formation by oral streptococci. Appl. Surf. Sci. 2016, 390, 602-607. [CrossRef]

146. Fujiwara, N.; Murakami, K.; Yoshida, K.; Sakurai, S.; Kudo, Y.; Ozaki, K.; Hirota, K.; Fujii, H.; Suzuki, M.; Miyake, Y.; et al. Suppressive effects of 2-methacryloyloxyethyl phosphorylcholine (MPC)-polymer on the adherence of Candida species and MRSA to acrylic denture resin. Heliyon 2020, 6, e04211. [CrossRef] [PubMed]

147. Türkcan, I.; Nalbant, A.D.; Bat, E.; Akca, G. Examination of 2-methacryloyloxyethyl phosphorylcholine polymer coated acrylic resin denture base material: Surface characteristics and Candida albicans adhesion. J. Mater. Sci. Mater. Med. 2018, $29,107$. [CrossRef]

148. Liu, T.; Xu, C.; Hong, L.; Garcia-Godoy, F.; Hottel, T.; Babu, J.; Yu, Q. Effects of trimethylsilane plasma coating on the hydrophobicity of denture base resin and adhesion of Candida albicans on resin surfaces. J. Prosthet. Dent. 2017, 118, 765-770. [CrossRef]

149. Acosta, L.D.; Pérez-Camacho, O.; Acosta, R.; Escobar, D.M.; Gallardo, C.A.; Sánchez-Vargas, L.O. Reduction of Candida albicans biofilm formation by coating polymethyl methacrylate denture bases with a photopolymerized film. J. Prosthet. Dent. 2020, 124, 605-613. [CrossRef] 
150. De Oliveira Limírio, J.P.J.; Gomes, J.M.L.; Alves Rezende, M.C.R.; Lemos, C.A.A.; Rosa, C.; Pellizzer, E.P. Mechanical properties of polymethyl methacrylate as a denture base: Conventional versus CAD-CAM resin-A systematic review and meta-analysis of in vitro studies. J. Prosthet. Dent. 2021. [CrossRef]

151. Liao, W.; Zheng, S.; Chen, S.; Zhao, L.; Huang, X.; Huang, L.; Kang, S. Surface silanization and grafting reaction of nano-silver loaded zirconium phosphate and properties strengthen in 3D-printable dental base composites. J. Mech. Behav. Biomed. Mater. 2020, 110, 103864. [CrossRef]

152. Mangal, U.; Min, Y.J.; Seo, J.-Y.; Kim, D.-E.; Cha, J.-Y.; Lee, K.-J.; Kwon, J.-S.; Choi, S.-H. Changes in tribological and antibacterial properties of poly(methyl methacrylate)-based 3D-printed intra-oral appliances by incorporating nanodiamonds. J. Mech. Behav. Biomed. Mater. 2020, 110, 103992. [CrossRef]

153. Simoneti, D.M.; Pereira-Cenci, T.; Dos Santos, M.B.F. Comparison of material properties and biofilm formation in interim single crowns obtained by 3D printing and conventional methods. J. Prosthet. Dent. 2020. [CrossRef] 